\title{
The Effect of Informal Tourist Trails on the Abiotic Conditions and Floristic Composition of Deciduous Forest Undergrowth in an Urban Area
}

\author{
Kinga Kostrakiewicz-Gierałt ${ }^{1, *(\mathbb{D}}$, Artur Pliszko ${ }^{2}$ AD $^{-}$and Katarzyna Gmyrek ${ }^{1}(\mathbb{D})$ \\ 1 Department of Tourism Geography and Ecology, Institute of Tourism, Faculty of Tourism and Recreation, \\ University of Physical Education in Cracow, Jana Pawła II 78, 31-571 Cracow, Poland; \\ katarzyna.gmyrek@awf.krakow.pl \\ 2 Department of Taxonomy, Phytogeography, and Palaeobotany, Institute of Botany, Faculty of Biology, \\ Jagiellonian University, Gronostajowa 3, 30-387 Cracow, Poland; atur.pliszko@uj.edu.pl \\ * Correspondence: kinga.kostrakiewicz@awf.krakow.pl
}

check for updates

Citation: Kostrakiewicz-Gierałt, K.; Pliszko, A.; Gmyrek, K. The Effect of Informal Tourist Trails on the Abiotic Conditions and Floristic Composition of Deciduous Forest Undergrowth in an Urban Area. Forests 2021, 12, 423. https://doi.org/10.3390/f12040423

Academic Editor: Idalia Kasprzyk

Received: 20 February 2021

Accepted: 29 March 2021

Published: 1 April 2021

Publisher's Note: MDPI stays neutral with regard to jurisdictional claims in published maps and institutional affiliations.

Copyright: (c) 2021 by the authors. Licensee MDPI, Basel, Switzerland. This article is an open access article distributed under the terms and conditions of the Creative Commons Attribution (CC BY) license (https:/ / creativecommons.org/licenses/by/ $4.0 /)$.

\begin{abstract}
The study aimed to assess the effect of informal tourist trails on the abiotic conditions and floristic composition of deciduous forest undergrowth in an urban area. The study was carried out in the Wolski Forest in Kraków (Poland) in 2020 using a total of 400 plots $(1 \mathrm{~m} \times 1 \mathrm{~m})$ situated in close (CL) and further (FU) vicinity of informal ( $<50 \mathrm{~cm}$ in width) and formal ( $\geq 150 \mathrm{~cm}$ in width) tourist trails in the forest interior and forest edge sites.Agreater content of $\mathrm{N}-\mathrm{NH} 4, \mathrm{P}$, and $\mathrm{K}$ occurred in the forest interior sites, while greater light intensity, species number, total plant cover, and stem height were found in the forest edge sites. Greater light intensity and a higher percentage of total and damaged plant cover were recorded in CLplots, while a greater height of plants was seen in FUplots. The number of species was higher in plots located along informal trails than in plots along formal trails. The dominance of therophytes and autochorous species along informal trails in the forest interior sites might be a result of successful diaspore dispersal by people walking, while the substantial share of zoochorous species along formal trails suggests their dissemination by dogs accompanying visitors. The dominance of forest and ruderal taxa in the forest interior sites suggests unfavourable conditions for the germination of meadow and grassland species. The higher coverabundance of alien plants in CL plots along informal trails and FU plots along formal traits suggests that alien plants growing near the formal trails are more exposed to mechanical damage.
\end{abstract}

Keywords: plant traits; soil properties; species composition; urban forest

\section{Introduction}

Urban forests, which constitute large areas of urban greenery, play a major role in the functioning of cities. The most often emphasised values of urban forest areas are favourable climatic conditions, varied topography, significant biodiversity, and the presence of water reservoirs. Good communication with the city centre makes them attractive places for active rest and recreation, ensuring the well-being and health of residents and tourists $[1,2]$. The importance of urban forests for recreation has been confirmed by many authors [3-11].

On the other hand, the development of tourism and recreation can be a serious threat to urban forests. The negative consequences of the excessive tourist traffic are represented, among others, by sewage production, air pollution, waste generation, noise, increased probability of fire ignition, scaring away of animals, as well as trampling due to illegal pathways. The establishment of spontaneous (informal) paths by tourists, runners, and cyclists significantly affects the soil conditions and species composition of the patches located in the vicinity of the trails [12]. The impact of spontaneous treading of informal paths on soil properties and/or vegetation in patches located in the vicinity of trails in urban forests is of increasing interest among researchers. Hitherto, investigations have focused on the effects of formal and informal trails on forest strata [13-18], soil 
microbial community [19], and soil physical and chemical properties $[15,16]$ as well as the impact of illegal trails on habitat fragmentation [20]. Nevertheless, the current state of knowledge is still insufficient; the impact of informal tourist trails on soil properties and vegetation characteristics still constitutes one of the main issues requiring further investigation, according to Ballantine and Pickering [21]. In this study, therefore, we aimed to assess the influence of informal tourist trails on the abiotic conditions and floristic composition of deciduous forest undergrowth. The specific goals were to investigate the effect of (i) the type of tourist trails (informal and formal), (ii) the distance from the trails, and (iii) the location of tourist trails in the forest interior and forest edge sites on

- Selected abiotic conditions (light intensity on the forest floor, soil moisture, $\mathrm{pH}$, and chemical properties).

- Plant cover features (number of species, total plant cover, the height of the tallest plants, and plantcover damaged by trampling).

- Cover-abundance of species representing different life forms, dispersal modes, habitat affiliations, and origin.

\section{Materials and Methods}

\subsection{The Study Area}

The study was conducted in the Wolski Forest (in Polish: "Las Wolski"), Lesser Poland Voivodeship, southern Poland. The Wolski Forest lies in the Polish Jurassic Highland, in the western part of the city of Kraków (Figure 1A), and covers ca. 420 ha. The highest elevated hills are Sowiniec (358 $\mathrm{m}$ a.s.l.), Pustelnik (352 $\mathrm{m}$ a.s.l.), and Srebrna Góra (326 m a.s.1.) [22] The geological substrate of the Wolski Forest consists of Upper Jurassic limestones and loess formations of various thickness, on which brown soils rich in nutrients, as well as black earth and alluvial soil, developed [22,23]. The loess soils are strongly exposed to water erosion, especially on slopes [24]. The Wolski Forest is situated in the temperate climate zone, with an average annual air temperature of about $9{ }^{\circ} \mathrm{C}$ and average annual precipitation of about $700 \mathrm{~mm}$ [25]. The area is very diverse in terms of microclimate. In summer, the south-facing limestone rocks heat up to $60^{\circ} \mathrm{C}$, whereas in shady gorges, the air is humid, with a temperature lower than $20^{\circ} \mathrm{C}$ [26]. The Wolski Forest is occupied by temperate deciduous forests - with beech and oak as dominant species-covering about $89 \%$ of the area. The highest situated areas are overgrown by a mixed forest (Pino-Quercetum Mat. et Polak.), while the shady gorges, by oak-hornbeam forest (Tilio-Carpinetum Anonim). On the north-facing shady slopes, Carpathian beech woodland (Dentario glandulosae-Fagetum W.Mat. ex Guzikowa et Kornaś) is present. The shady steep rocky walls are covered by mosses and ferns, and the open calcareous south-facing rocky walls and shelves favour the development of xerothermic thickets and saxatile grasslands. Moreover, the forest clearings of the Wolski Forest are occupied by semi-natural (Molinio-Arrhenatheretea R.Tx.) and anthropogenic (Artemisietea vulgaris Lohm., Prsg et R.Tx. in R.Tx.) vegetation [23,26-28].

The Wolski Forest is the largest green area in Kraków and belongs to agroup of municipal forests [24]. In 1981, it was included in the Bielańsko-Tyniecki Landscape Park due to its high natural value. There are three nature reserves within the Wolski Forest, one of which (Panieńskie Skały, 6.41 ha) protects a 150-year-old tree stand [24]. Apart from natural, landscape, and historical values, the Wolski Forest plays a major recreational role for Kraków's citizens, and it is an undisputed tourist attraction [22,24,27]. There are several recreational clearings within the Wolski Forest, namely Polana Sowiniec (4.2 ha), Polana Bielańska (1.7 ha), PolanaJacka Malczewskiego (1 ha), Polana Juliusza Lea (0.9 ha), Polana Wincentego Wobra (0.9 ha), and Polana Harcerska (0.1 ha). Moreover, there are eight marked hiking trails, a cycling path, a horse-riding trail, and a cross-country skiing route. The most popular tourist attractions are the Kraków Zoo, the Przegorzały Castle, the Pilsudski Mound, and the Camaldolese Monastery [22,27]. In the Wolski Forest, plant communities have been negatively impacted by improper forest management and the planting of alien tree species such as Aesculus hippocastanum L., Pinus nigra J.F.Arnold, P. strobus L., Quercus rubra L., and Robinia pseudoacacia L. In addition, citizens and tourists contribute to 
the destruction of habitats and the loss of native species by trampling, dumping rubbish, and collecting rare plants $[23,24,26]$.

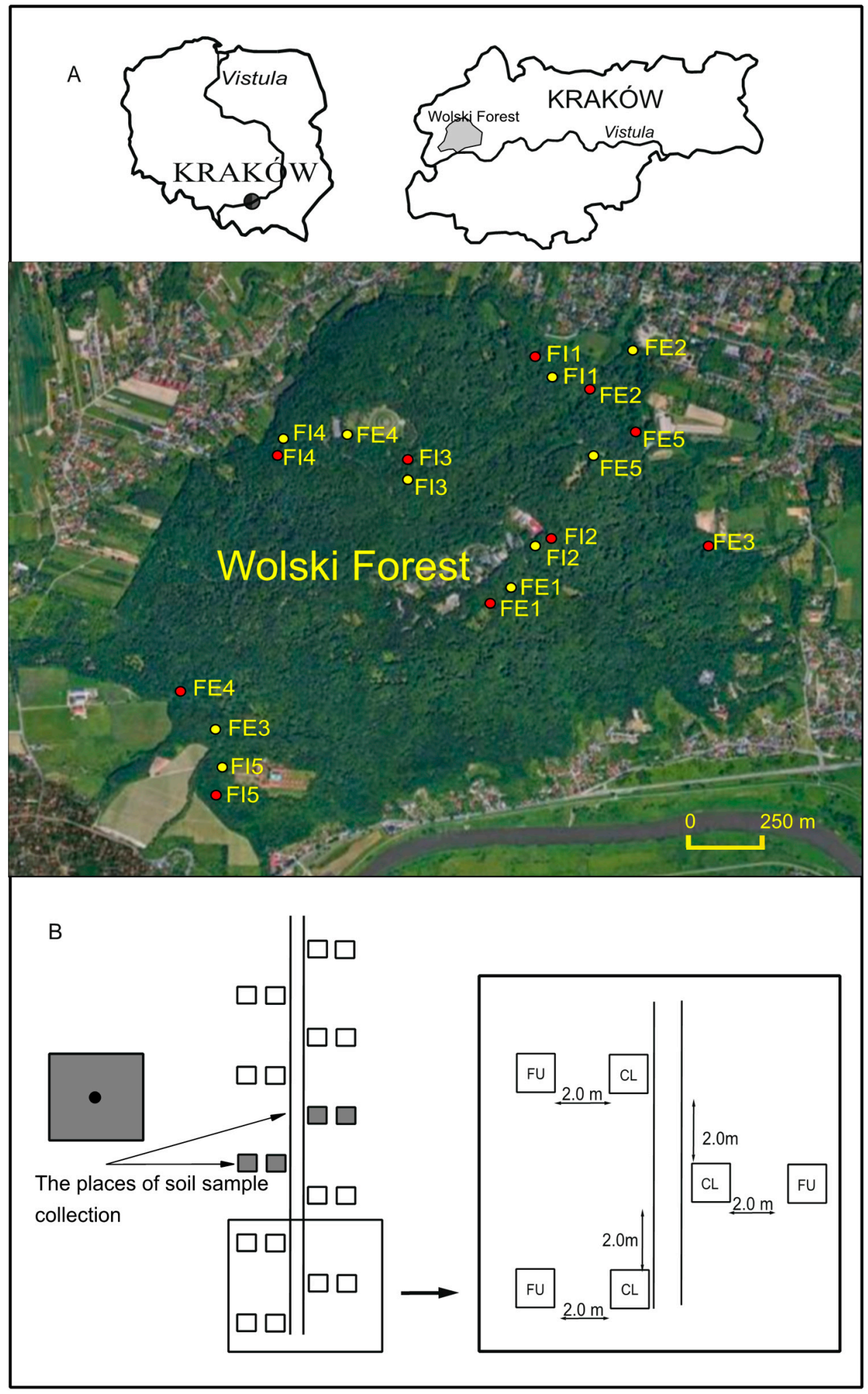

Figure 1. Location of the study sites (A) and the sampling design (B). Abbreviations of study sites are explained in Table 1; yellow circles mean formal trails, red circles mean informal trails; CL indicates the plot located near the trail, FU indicates the plot located far from the trail. 
Table 1. The characteristics of study sites.

\begin{tabular}{|c|c|c|c|c|c|c|c|}
\hline \multirow{2}{*}{$\begin{array}{l}\text { Study Site } \\
\text { Location }\end{array}$} & \multirow{2}{*}{$\begin{array}{l}\text { Study Site } \\
\text { Code }\end{array}$} & \multicolumn{2}{|c|}{ Width of Trail $(\mathrm{cm})$} & \multicolumn{2}{|c|}{ GPS Coordinates of Trail } & \multicolumn{2}{|c|}{ Elevation of Trail (m) } \\
\hline & & Informal & Formal & Informal & Formal & Informal & Formal \\
\hline \multirow{5}{*}{$\begin{array}{l}\text { Forest } \\
\text { interior }\end{array}$} & FI1 & 35 & 155 & $\begin{array}{l}\mathrm{N} 50^{\circ} 03.749^{\prime} \\
\mathrm{E} 19^{\circ} 51.263^{\prime}\end{array}$ & $\begin{array}{l}\mathrm{N} 50^{\circ} 03.740^{\prime} \\
\mathrm{E} 19^{\circ} 51.337^{\prime}\end{array}$ & 328 & 290 \\
\hline & FI2 & 49 & 200 & $\begin{array}{l}\mathrm{N} 50^{\circ} 03.287^{\prime} \\
\mathrm{E} 19^{\circ} 51.405^{\prime}\end{array}$ & $\begin{array}{l}\mathrm{N} 50^{\circ} 03.287^{\prime} \\
\mathrm{E} 19^{\circ} 51.298^{\prime}\end{array}$ & 335 & 344 \\
\hline & FI3 & 44 & 260 & $\begin{array}{l}\mathrm{N} 50^{\circ} 03.478^{\prime} \\
\mathrm{E} 19^{\circ} 50.910^{\prime}\end{array}$ & $\begin{array}{l}\mathrm{N} 50^{\circ} 03.456^{\prime} \\
\mathrm{E} 19^{\circ} 50.919^{\prime}\end{array}$ & 334 & 363 \\
\hline & FI4 & 35 & 210 & $\begin{array}{l}\mathrm{N} 50^{\circ} 03.556^{\prime} \\
\mathrm{E} 19^{\circ} 50.521^{\prime}\end{array}$ & $\begin{array}{l}\mathrm{N} 50^{\circ} 03.561^{\prime} \\
\mathrm{E} 19^{\circ} 50.509^{\prime}\end{array}$ & 331 & 321 \\
\hline & FI5 & 50 & 190 & $\begin{array}{l}\mathrm{N} 50^{\circ} 02.683^{\prime} \\
\mathrm{E} 19^{\circ} 50.311^{\prime}\end{array}$ & $\begin{array}{l}\mathrm{N} 50^{\circ} 02.780^{\prime} \\
\mathrm{E} 19^{\circ} 50.275^{\prime}\end{array}$ & 239 & 291 \\
\hline \multirow{5}{*}{ Forest edge } & FE1 & 31 & 237 & $\begin{array}{l}\mathrm{N} 50^{\circ} 03.187^{\prime} \\
\mathrm{E} 19^{\circ} 51.249^{\prime}\end{array}$ & $\begin{array}{l}\mathrm{N} 50^{\circ} 03.181^{\prime} \\
\mathrm{E} 19^{\circ} 51.216^{\prime}\end{array}$ & 341 & 339 \\
\hline & FE2 & 48 & 110 & $\begin{array}{l}\mathrm{N} 50^{\circ} 03.657^{\prime} \\
\mathrm{E} 19^{\circ} 51.529^{\prime}\end{array}$ & $\begin{array}{l}\mathrm{N} 50^{\circ} 03.799^{\prime} \\
\mathrm{E} 19^{\circ} 51.664^{\prime}\end{array}$ & 323 & 255 \\
\hline & FE3 & 38 & 190 & $\begin{array}{l}\mathrm{N} 50^{\circ} 03.294^{\prime} \\
\mathrm{E} 19^{\circ} 52.017^{\prime}\end{array}$ & $\begin{array}{l}\mathrm{N} 50^{\circ} 02.865^{\prime} \\
\mathrm{E} 19^{\circ} 50.345^{\prime}\end{array}$ & 272 & 285 \\
\hline & FE4 & 48 & 250 & $\begin{array}{l}\mathrm{N} 50^{\circ} 02.927^{\prime} \\
\mathrm{E} 19^{\circ} 50.077^{\prime}\end{array}$ & $\begin{array}{l}\mathrm{N} 50^{\circ} 03.567^{\prime} \\
\mathrm{E} 19^{\circ} 50.756^{\prime}\end{array}$ & 290 & 359 \\
\hline & FE5 & 34 & 290 & $\begin{array}{l}\mathrm{N} 50^{\circ} 03.526^{\prime} \\
\mathrm{E} 19^{\circ} 51.741^{\prime}\end{array}$ & $\begin{array}{l}\text { N50 } 03.437^{\prime} \\
\text { E19 } 51.466^{\prime}\end{array}$ & 284 & 326 \\
\hline
\end{tabular}

\subsection{The Plot Sampling Design}

Ten locations of plot sampling were selected, including five locations within the forest interior (FI) and five locations on the forest edges (FE). In each location, two pathways, one narrow (up to $50 \mathrm{~cm}$ in width) and one wide (at least $150 \mathrm{~cm}$ in width), were selected. The narrow pathways were spontaneously created by visitors and served as informal tourist trails, whereas the wide pathways represented formal tourist trails and were treated as a control group. The forest interior trails were located inside closed canopy stands, whereas the forest edge trails were in open areas but no more than $20 \mathrm{~m}$ from the fully stocked stands, including vegetation of clearings and other open places outside the forest. The detailed location of the trails is given in Table 1 . Ten pairs of $1 \mathrm{~m} \times 1 \mathrm{~m}$ research plots were established along each trail. The pairs were systematically distributed every $2 \mathrm{~m}$ (alternately on both sides of the path). Each pair consisted of a plot labelled CL (close), located $10 \mathrm{~cm}$ from the edge of the trail, and a plot labelled FU (further), located $2 \mathrm{~m}$ from the CL plots. A total of 400 plots were recorded. The side of the trail (left or right) where the plot sampling began was randomly selected by a coin toss. However, if any next plot selected according to the sampling scheme was in a place occupied by a fallen tree or a trunk of a large tree, a new plot was established on the same side of the trail, maintain a2 $\mathrm{m}$ distance from the previous plot. The location of study sites and plot sampling design are presented in Figure 1.

\subsection{The Measurement of Abiotic Traits within the Plots}

Field studies were conducted in June and July 2020. In the central part of each plot, the light intensity at ground level, soil reaction, and soil moisture were measured. The values of the light intensity were measured using a Volt craft LX-10 0-199900 lx. The soil reaction and moisture were measured using a handheld BIOWIN device. The range of the moisture scale was from 1 to 10 , where values 1-3 indicated dry soils, 4-7 humid soils, and 8-10 wet soils. Additionally, a total of 80 soil samples were collected using a stainless steel soil spatula. They were taken in the CL and FU plots, located in pairs 5 and 6 along the 
tourist trails (Figure 1B). Thick, matted roots and gravel at or near the soil surface were removed before the sample collecting. Soil samples were collected from the central part of the plots. The equal soil samples weighing ca. $0.5 \mathrm{~kg}$ were taken from the top of the soil horizon to the depth of $10 \mathrm{~cm}$ below the ground surface. The samples were kept in paper bags not fully closed to allow gas exchange. In the laboratory, the soil samples were sieved $(2 \mathrm{~mm})$ and subjected to chemical analyses. The content of phosphorus (P), potassium (K), nitrite (N-NO2), nitrate (N-NO3), and ammonium nitrogen (N-NH4) were determined using VISOCOLOR ${ }^{\circledR}$ kit (Macherey-Nagel), which assures the high quality and accuracy of results.

\subsection{The Measurement of Plant Cover Traits within the Plots}

The height of the tallest plant shoot of the undergrowth was measured in each study plot using a folder tape. The percentage of total plant cover and the percentage of plant cover damaged by trampling were visually evaluated within each plot in the undergrowth. Furthermore, for each plot, the vascular plant species growing in the undergrowth were determined. The seedlings and saplings were determined according to Csapodý [29] and Muller [30]. The number of species growing in each plot was calculated. The cover-abundance of each species was visually estimated according to the Braun-Blanquet scale [31]. The explication of points on the scale is as follows:

- " $+"$ - species covers less than $1 \%$ of the plot area.

- " 1 "- -species covers $1 \%-5 \%$ of the plot area.

- " 2 "- -species covers $6 \%-25 \%$ of the plot area.

- $\quad 3$ "- -species covers $26 \%-50 \%$ of the plot area.

- $\quad 4$ "- -species covers $51 \%-75 \%$ of the plot area.

- $\quad$ " 5 "- species covers $76 \%-100 \%$ of the plot area.

\subsection{The Selection of Ecological Traits of the Species}

To assess the species response to tourist activities, we selected plant traits that were thought to be "ecologically meaningful" concerning persistence in the stressful environments caused by activities of humans (trampling) and accompanying animals (ground browning, wallowing). These included life form, dispersal mode, habitat affiliation, and species origin (native or alien). The list of species recorded in the plots is presented in Table A1.

The life form of species proposed by Raunkiaer was assigned based on the Pladias Database [32]. The following life forms were distinguished: phanerophytes (PH), lianas $(\mathrm{L})$, chamaephytes $(\mathrm{CH})$, hemicryptophytes $(\mathrm{H})$, geophytes $(\mathrm{G})$, and therophytes $(\mathrm{T})$. In the case of the occurrence of more than one life form, the first one was chosen.

The dispersal mode of species was assigned using the PladiasDatabase [32]. The following dispersal types were distinguished: Allium (mainly autochory, as well as anemochory, endozoochory, and epizoochory), Bidens (mainly autochory and epizoochory, as well as endozoochory), Cornus (autochory and endozoochory), Epilobium (mainly anemochory and autochory, as well as endozoochory andepizoochory), Lycopodium (mainly anemochory, as well as autochory, endozoochory, epizoochory, and hydrochory), Sparganium (mainly autochory and hydrochory), and Zea (dispersal strategy rarely or never dispersed by generative diaspores and do not form vegetative aboveground diasporas). The full description of dispersal modes isprovided by Sádlo et al. [33].

Habitat affiliation of species appearing in the plots was assigned according to Matuszkiewicz [34]. Particular species were assigned to (i) forest species (occurring in European mesotrophic and eutrophic deciduous forests from the Querco-Fagetea Br.-Bl. et Vlieg. class; acidophilic, oligotrophic, and mesotrophic deciduous forests with a predominance of oaks from the Quercetea robori-petraeae Br.-Bl. et R. Tx. class; alder and shrub thickets from the Alnetea glutinosae Br.-Bl. et R.Tx. class; coniferous forests from Vaccinio-Piceetea Br.-Bl. class; shrub formations functionally related to the forest from Crataego-Prunetea Tx.), (ii) grassland species (occurring in calcareous grasslands from the Festuco-Brometea Br.-Bl. et R.Tx. class; thermophilic fringe communities representing the Cratego-Prunetea 
and Trifolio-Geranietea sanguinei Th. Müller classes; sandy grasslands Koelerio glaucaeCorynephoretea canescentis Klika in Klika et Novak), (iii) meadow species (occurring in communities representing the semi-natural and anthropogenic turf meadow communities from the Molinio-Arrhenatheretea class and alpine herbal and herbaceous plants from the Betulo-Adenostyletea Br.-Bl. class), and (iv) ruderal species (occurring in ruderal communities of perennial plants from the Artemisietea vulgaris class; natural and semi-natural nitrophilous communities from the Galio-Urticenea (Pass.) Th. Müller in Oberd. subclass; moderately nitrophilous communities of summer therophytes Bidentetea tripartitii R.Tx., Lohm. et Prsg; nitrophilous communities of logging, trampled, and ruderal areas from the Epilobietea angustifolii R.Tx. et Prsg class; semi-ruderal xerothermic pioneer communities from the Agropyretea intermedio-repentis (Oberd. et all.) Müller et Görs class; communities of arable fields and ruderal sites from the Stellarietea mediae R.Tx., Lohm. et Prsg 1950 class; communities of small therophytes on moist and wet mineral substrates from the Isoëto-Nanojuncetea Br.-Bl. et R.Tx. class).

The origin of species was assigned based on the Alien species in Poland database [35] and references therein; the alien and native taxa were distinguished according to this source. The alien species was understood as a species or lower taxon, introduced outside its natural past or present range, that might survive and subsequently reproduce. The native species to a given area is a species that has been observed in the form of a naturally occurring and self-sustaining population from historical times. The invasive status of alien species was also assigned following the Alien species in Poland database [35] and references therein. Plants determined solely on genera, such as Epilobium sp. and Rubus sp., were excluded from the analyses. Moreover, cultivated plants such as Malus domestica Borkh., Lolium multiflorum Lam., and Ribesuva-crispa L. were excluded from the analysis of habitat affiliation.

\subsection{The Data Analysis}

The mean light intensity, soil moisture, soil reaction, height of the tallest plant shoot, number of species, percentage of plant cover damaged by trampling, and percentage of total plant cover were calculated separately in each CL and FU plot located along the informal and formal tourist trails in the forest interior and forest edge sites.

The normal distribution of the untransformed data was tested using the KołmogorovSmirnov test, whereas the homogeneity of variance was verified using the Levene test at the significance level of $p<0.05$.

The Student's $t$-test was used to test the statistical significance of differences in (i) light intensity, (ii) soil moisture, (iii) soil reaction, (iv) height of the tallest plant shoot, (v) number of species, (vi) percentage of total plant cover, and (vii) percentage of plant cover damaged by trampling between plots located

(i) at a different distance from tourist trails,

(ii) along informal and formal tourist trails, and

(iii) in forest interior and forest edge sites.

The Mann-Whitney U test was applied to check the statistical significance of differences in the content of $\mathrm{P}, \mathrm{K}, \mathrm{N}-\mathrm{NO} 2, \mathrm{~N}-\mathrm{NO} 3$, and N-NH4 between plots located

(i) at a different distance from tourist trails,

(ii) along informal and formal tourist trails, and

(iii) in forest interior and forest edge sites.

The analyses were computed using STATISTICA software (version 13).

The chi-square test with Yates correction for continuity was applied to check whether there were significant differences between the plots located in the forest interior and forest edge sites, along informal and formal tourist trails, as well as in the plots located at diverse distances from the border of trails with regard to the cover-abundance degree of species representing various life forms, dispersal modes, habitat affiliations, and origins. The chi-square test was conducted using the interactive calculation tool [36]. 


\section{Results}

\subsection{The Characteristics of Light Intensity and Soil Conditions}

The mean light intensity in the CL and FU plots located along informal and formal tourist trails in the forest interior and forest edge sites ranged from $711.2 \mathrm{~lx}$ to 35,399.8 lx. The statistical analysis showed that light intensity was greater in CL plots than in FU plots (Figure 2). It did not differ between informal and formal tourist trail plots in the forest interior sites, and it was much greater along informal trails in the forest edge sites. The light intensity was significantly greater in the forest edge sites than in the forest interior sites. Such a tendency was found in $\mathrm{CL}(\mathrm{t}=-6.2, \mathrm{df}=98, p<0.001)$ and $\mathrm{FU}(\mathrm{t}=-3.7$, $\mathrm{df}=98, p<0.001)$ plots located along formal trails as well as in CL $(\mathrm{t}=-5.7, \mathrm{df}=98$, $p<0.001)$ and $\mathrm{FU}(\mathrm{t}=-4.6, \mathrm{df}=98, p<0.001)$ plots located along informal trails.

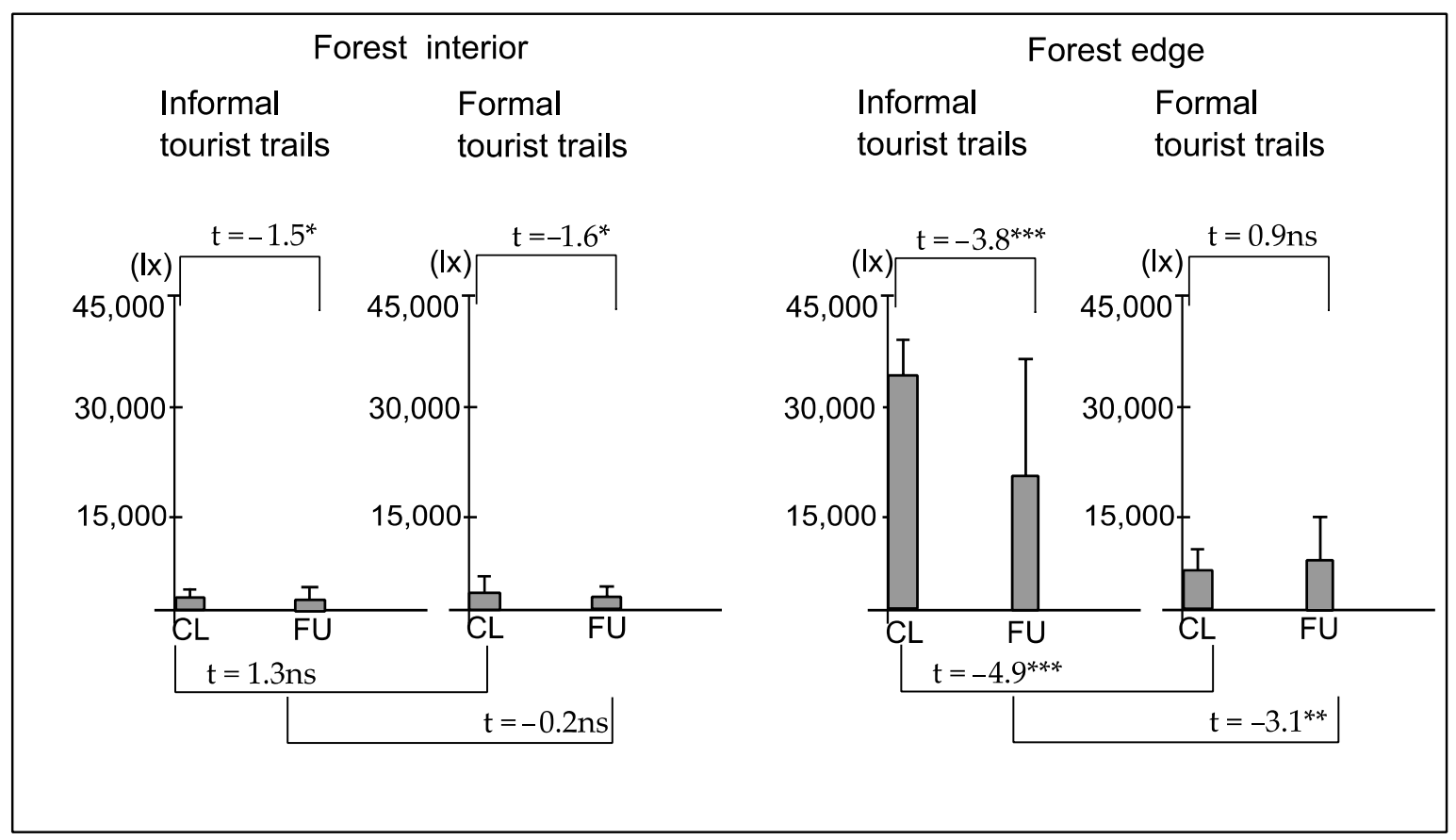

Figure 2. The mean values of light intensity (lx) at ground level $( \pm \mathrm{SD})$ in closer (CL) and further (FU) plots located along informal (width $<50 \mathrm{~cm}$ ) and formal (width $>150 \mathrm{~cm}$ ) tourist trails within the forest interior and forest edge sites. The statistical significance level: ns- not significant, ${ }^{*} p \leq 0.05,{ }^{* *} p<0.01,{ }^{* * *} p<0.001$.

The mean soil reaction ranged from 7.1 to 7.3 , and it did not differ significantly between CL and FU plots or between informal and formal tourist trail plots (Figure 3). The soil reaction was similar in the forest edge and forest interior sites in CL plots located along formal trails $(\mathrm{t}=0.15, \mathrm{df}=98, p=0.87)$ and in FU plots located along informal trails $(\mathrm{t}=0.09, \mathrm{df}=98, p=0.92)$. The soil $\mathrm{pH}$ was significantly greater in the forest edge sites in FU plots $(\mathrm{t}=-2.6, \mathrm{df}=98, p \leq 0.05)$ located along formal trails as well as in CL plots $(\mathrm{t}=-2.7, \mathrm{df}=98, p<0.01)$ located along informal trails.

The soil moisture, ranging from 4.7 to 5.5 on average, did not differ significantly between the CL and FU plots or between the informal and formal tourist trail plots (Figure 3). Moreover, it was similar in the forest edge and forest interior sites in CL plots located along formal trails $(\mathrm{t}=0.89, \mathrm{df}=98, p=0.37)$ and along informal ones $(\mathrm{t}=0.02, \mathrm{df}=98, p=0.98)$ as well as in FU plots located along informal trails $(\mathrm{t}=-1.76, \mathrm{df}=98, p=0.08)$. Higher levels of soil moisture in the forest edge sites were recorded in FU plots $(\mathrm{t}=-2.8, \mathrm{df}=98$, $p<0.01$ ) situated along formal trails. 


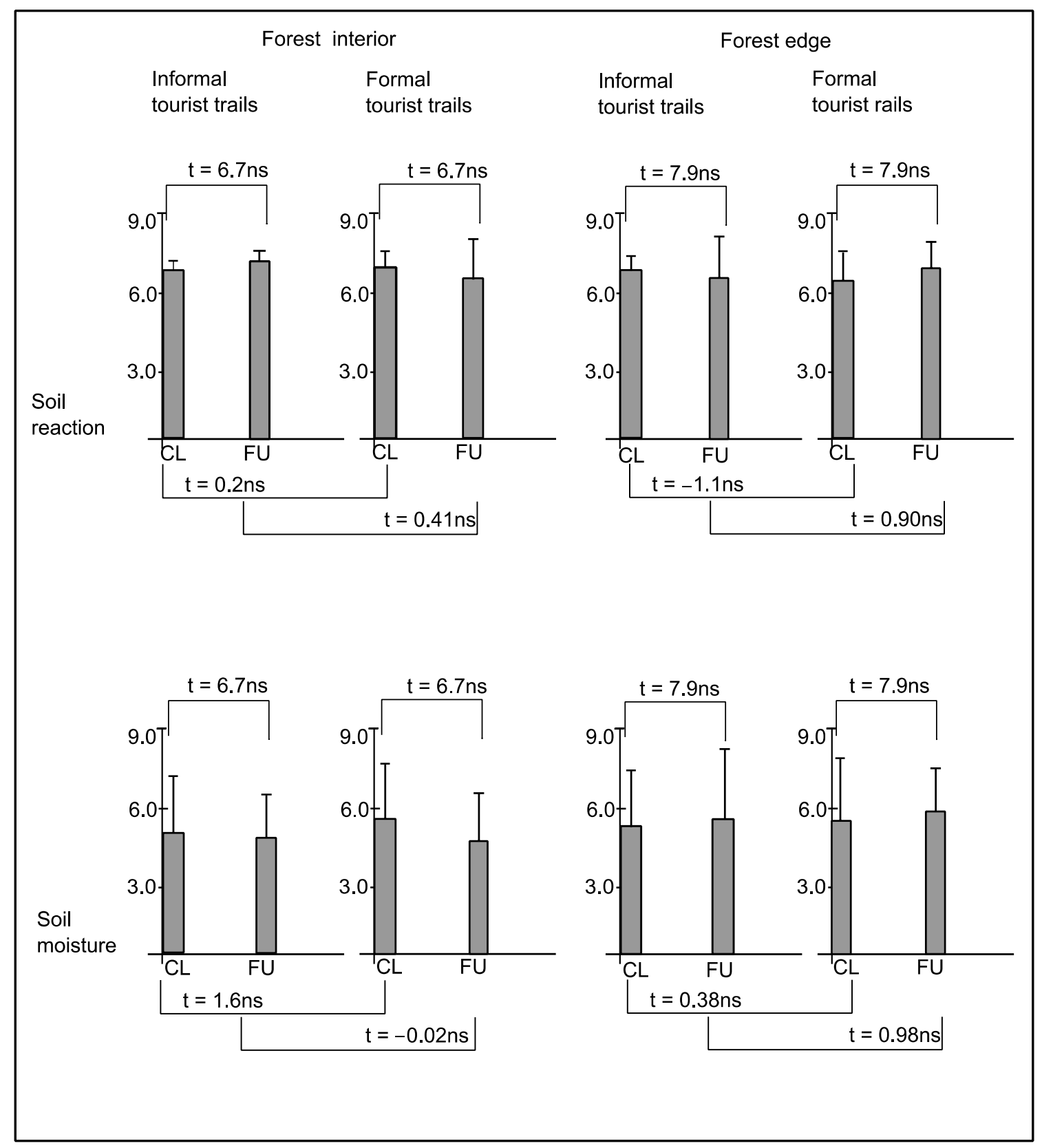

Figure 3. The mean values of soil reaction $( \pm S D)$ and soil moisture $( \pm S D)$ in closer $(C L)$ and further (FU) plots located along informal (width $<50 \mathrm{~cm}$ ) and formal (width $>150 \mathrm{~cm}$ ) tourist trails within the forest interior and forest edge sites. The statistical significance level is explained in Figure 2.

The mean content of ammonium nitrogen (N-NH4+) ranged from 0.78 to $25.35 \mathrm{mg} / \mathrm{kg}$ of soil, and it was similar in CL and FU plots as well as in informal and formal tourist trail plots (Figure 4). The mean content of N-NH4+ was markedly greater in forest interior sites in CL $(\mathrm{U}=18.5, p<0.01)$ and $\mathrm{FU}(\mathrm{U}=24.0, p \leq 0.05)$ plots located along informal trails as well as in $\mathrm{CL}(\mathrm{U}=18.0, p \leq 0.05)$ and $\mathrm{FU}(\mathrm{U}=18.0, p \leq 0.05)$ plots located along formal trails.

The mean content of nitrite (N-NO2) ranged from 0.4 to $3.0 \mathrm{mg} / \mathrm{kg}$, and it was similar in CL and FU plots as well as in informal and formal tourist trail plots (Figure 5). The mean content of $\mathrm{N}-\mathrm{NO} 2$ did not differ between forest interior and forest edge sites. Alack of difference was recorded in $\mathrm{CL}(\mathrm{U}=50.0, p=1.0)$ and $\mathrm{FU}(\mathrm{U}=45.0, p=0.73)$ plots located along formal trails as well as in $\mathrm{CL}(\mathrm{U}=45.0, p=0.73)$ and $\mathrm{FU}(\mathrm{U}=45.0, p=0.73)$ plots located along informal trails. 


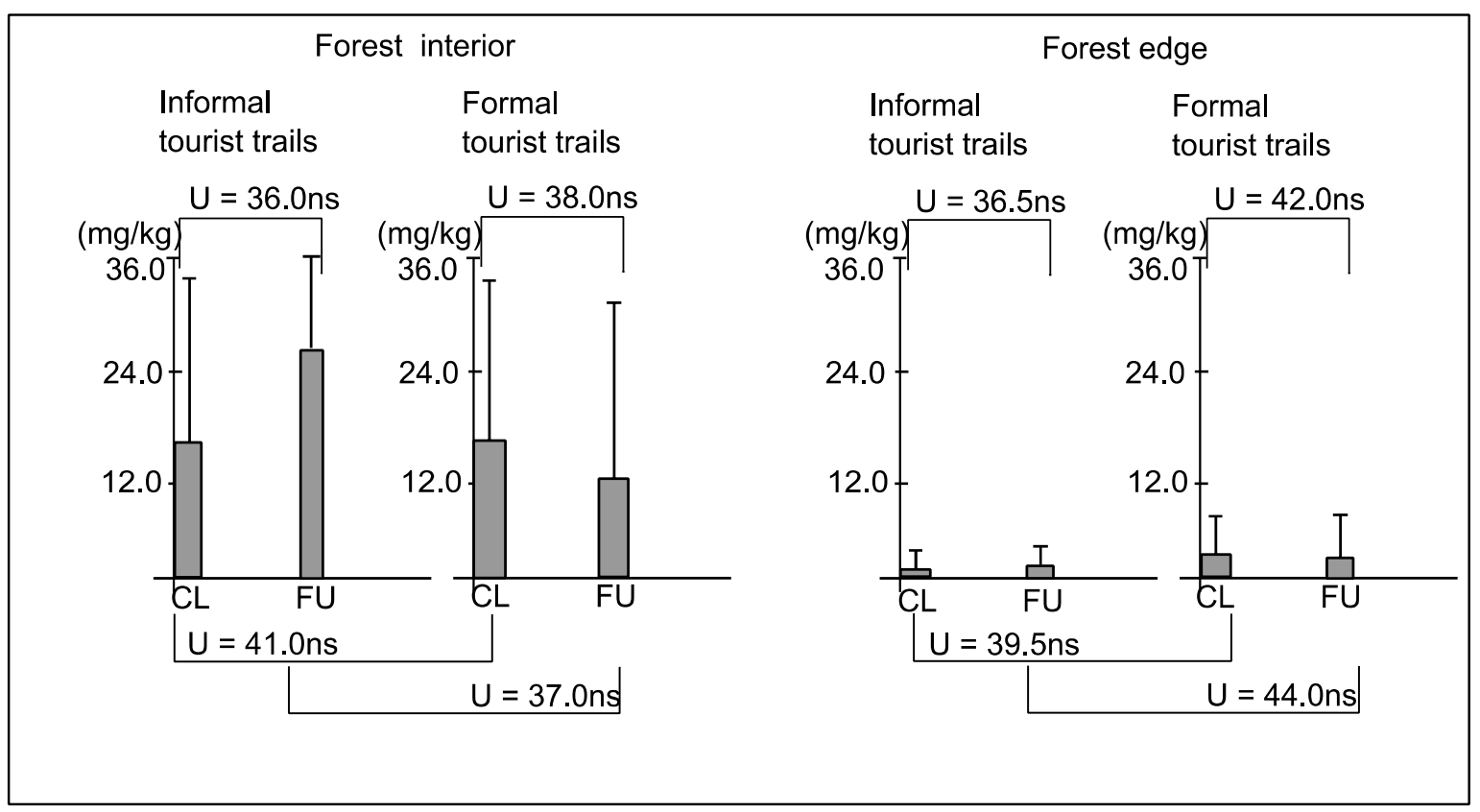

Figure 4. The mean content of ammonium nitrogen $\left(\mathrm{N}-\mathrm{NH}_{4}\right)$ in $\mathrm{mg} / \mathrm{kg}( \pm \mathrm{SD})$ in soil samples of closer (CL) and further (FU) plots located along informal (width $<50 \mathrm{~cm}$ ) and formal (width $>150 \mathrm{~cm}$ ) tourist trails within the forest interior and forest edge sites. The statistical significance level is explained in Figure 2.

The mean content of nitrate (N-NO3) ranged from 49.4 to $67.5 \mathrm{mg} / \mathrm{kg}$, and it did not differ between $\mathrm{CL}$ and FU plots or between informal and formal tourist trail plots (Figure 5). The mean content of nitrate (N-NO3) was similar in forest interior and forest edge sites. It was observed in CL ( $\mathrm{U}=46.5, p=0.82)$ and $\mathrm{FU}(\mathrm{U}=49.0, p=0.96)$ plots located along formal trails as well as in $\mathrm{CL}(\mathrm{U}=41.0, p=0.52)$ and $\mathrm{FU}(\mathrm{U}=35.0, p=0.27)$ plots located along informal trails.

The mean content of phosphorus ranged from 7.0 to $22.2 \mathrm{mg} / \mathrm{kg}$ of soil, and it did not differ between $\mathrm{CL}$ and FU plots or between informal and formal tourist trail plots (Figure 6). The mean content of phosphorus was greater in forest interior sites than in forest edge sites. The differences were recorded in $\mathrm{CL}(\mathrm{U}=19.5, p \leq 0.05)$ and $\mathrm{FU}(\mathrm{U}=17.0$, $p \leq 0.05)$ plots located along formal trails as well as in CL $(\mathrm{U}=14.0, p \leq 0.05)$ and FU $(\mathrm{U}=16.0, p \leq 0.05)$ plots located along informal trails.

The mean content of potassium ranged from 7.0 to $22.2 \mathrm{mg} / \mathrm{kg}$ of soil, and it was similar in CL and FU plots as well as in plots of informal and formal tourist trails (Figure 6). The mean content of potassium was significantly greater in forest interior sites than in forest edge sites in $\mathrm{CL}(\mathrm{U}=15.0, p \leq 0.05)$ and $\mathrm{FU}(\mathrm{U}=16.5 .0, p \leq 0.05)$ plots located along informal trails as well as in $\mathrm{CL}(\mathrm{U}=18.5, p \leq 0.05)$ and $\mathrm{FU}(\mathrm{U}=18.0, p \leq 0.05)$ plots located along formal trails.

\subsection{The Characteristics of Plant Cover Traits}

A total of 158 plant taxa were recorded in the study sites (Appendix A, Table A1). The mean number of species ranged from 4.3 to 10.0 and did not differ between CL and FU plots. However, it was significantly greater in informal tourist trail plots than in formal tourist trail plots, particularly in forest edge sites (Figure 7). The number of species was significantly greater in forest edge sites in CL $(\mathrm{t}=-3.3, \mathrm{df}=98, p<0.01)$ and FU $(\mathrm{t}=-4.8$, $\mathrm{df}=98, p<0.001)$ plots located along formal trails as well as in CL $(\mathrm{t}=-9.4, \mathrm{df}=98$, $p<0.001)$ and $\mathrm{FU}(\mathrm{t}=-10.1, \mathrm{df}=98, p<0.001)$ plots located along informal trails.

The height of the tallest stems of undergrowth plants ranged from $14.5 \mathrm{~cm}$ to $80.5 \mathrm{~cm}$ on average, and it was greater in FU than in CL plots. Moreover, it did not differ between informal and formal tourist trail plots located in the forest interior sites, while it was significantly greater along informal trails in the forest edge sites (Figure 7). The greater 
height of plant stems in the forest interior was noted in CL plots located along formal trails $(\mathrm{t}=-3.3, \mathrm{df}=98, p<0.01)$. Alack of difference among forest interior and forest edge sites was found in FU plots located along formal trails $(t=0.8, \mathrm{df}=98, p=0.42)$. Markedly greater values of undergrowth plant height in forest edge sites were recorded in $\mathrm{CL}(\mathrm{t}=-2.4, \mathrm{df}=98, p<0.01)$ and $\mathrm{FU}(\mathrm{t}=-4.6, \mathrm{df}=98, p<0.001)$ plots located along informal trails.

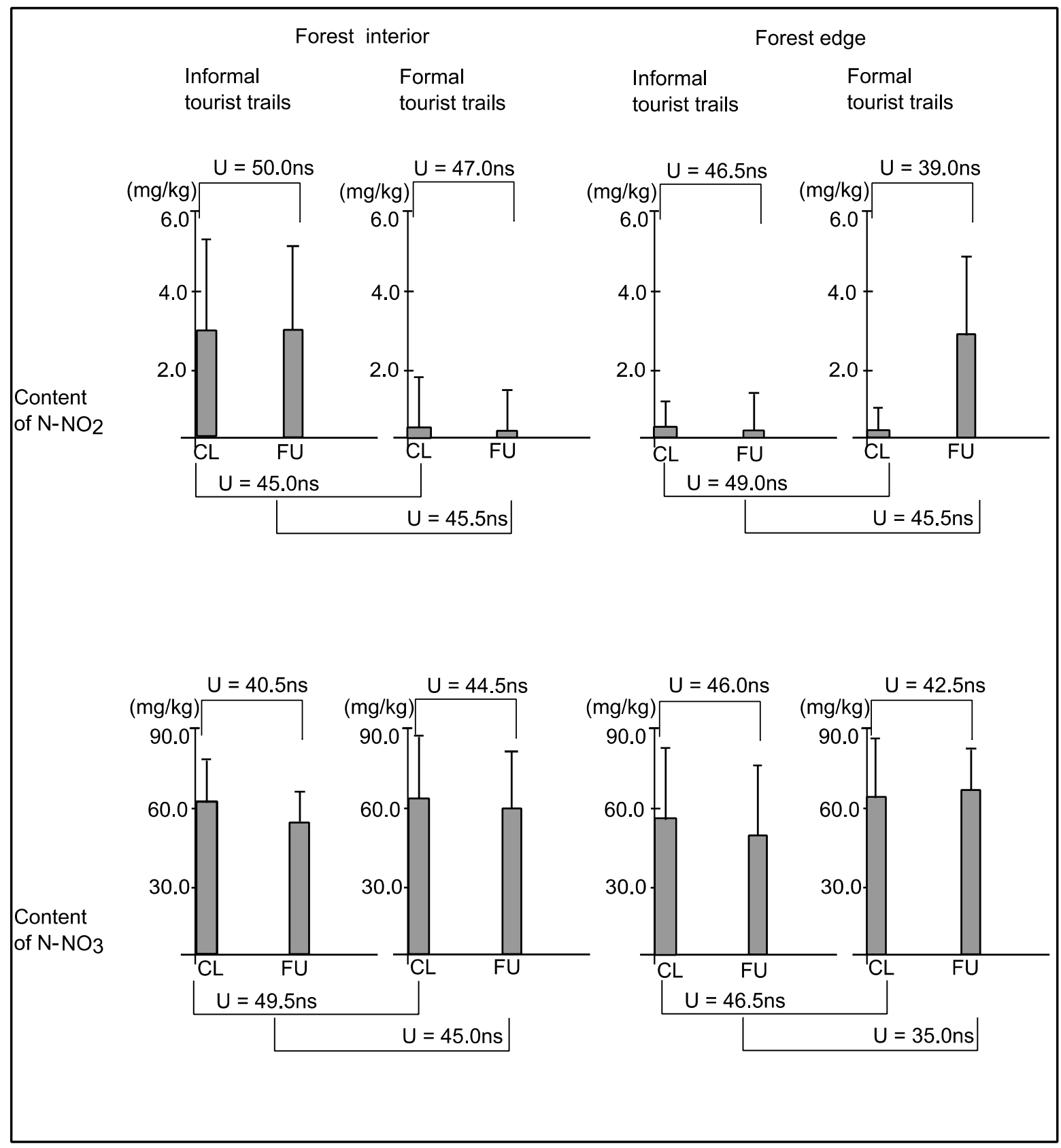

Figure 5. The mean content of nitrite $\mathrm{N}-\mathrm{NO}_{2}$ and nitrate $\mathrm{N}-\mathrm{NO}_{3}( \pm \mathrm{SD})$ in soil samples of closer (CL) and further (FU) plots located along informal (width $<50 \mathrm{~cm}$ ) and formal (width $>150 \mathrm{~cm}$ ) tourist trails within the forest interior and forest edge sites. The statistical significance level is explained in Figure 2.

The total plant cover percentage ranged from 36.8 to 71.4 on average, and it was significantly greater in CL than in FU plots located along informal tourist trails. Moreover, it was markedly greater along informal trails than along formal trails (Figure 8 ). The total plant cover had much greater values in forest edge sites than in the forest interior sites in 
$\mathrm{CL}(\mathrm{t}=-2.4, \mathrm{df}=98, p \leq 0.05)$ and FU plots located along formal trails $(\mathrm{t}=-2.5, \mathrm{df}=98$, $p \leq 0.05)$ as well as in $\mathrm{CL}(\mathrm{t}=-6.4, \mathrm{df}=98, p<0.001)$ and FU plots located along informal trails $(\mathrm{t}=-51, \mathrm{df}=98, p<0.001)$.

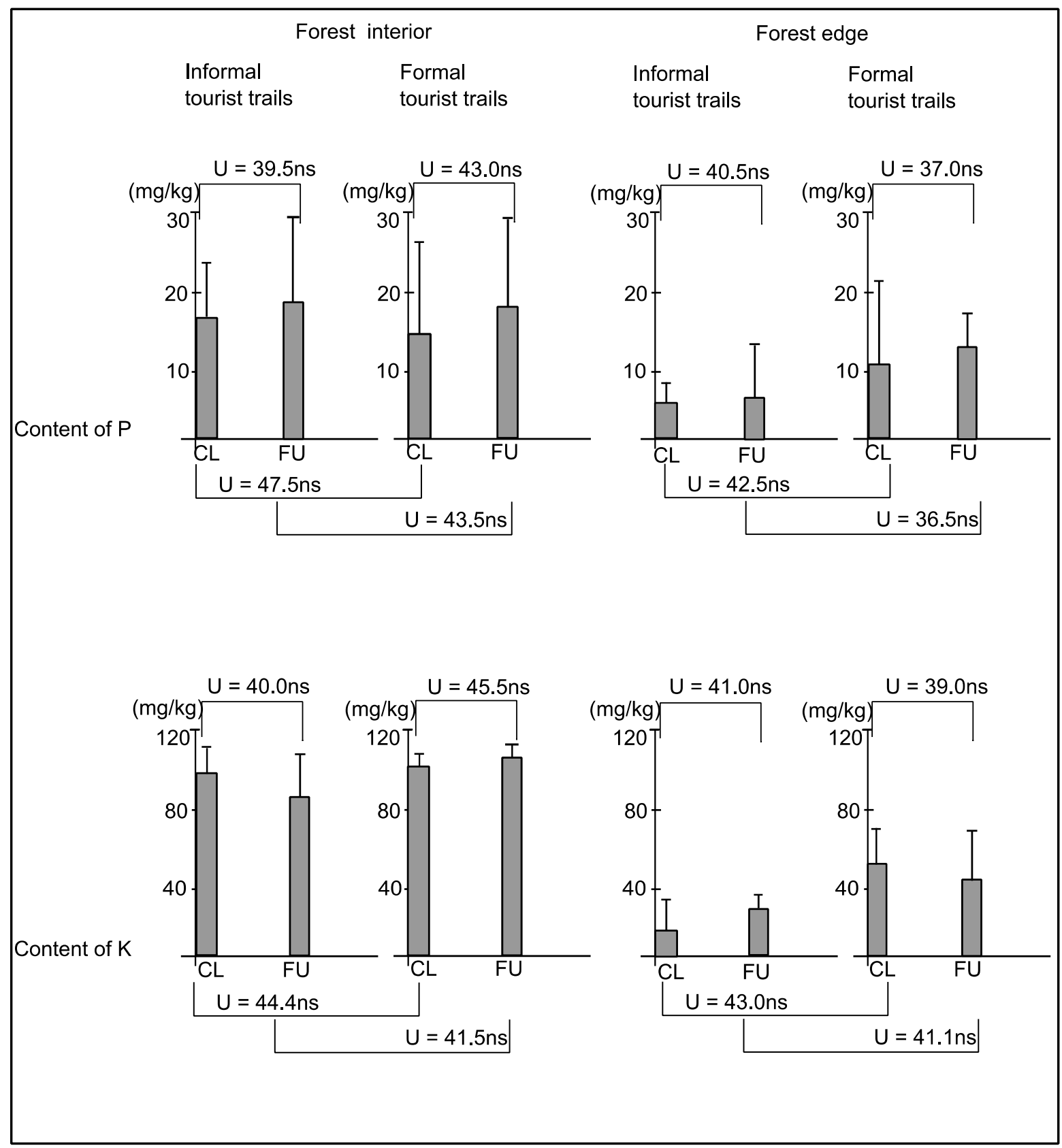

Figure 6. The mean content of phosphorus $( \pm S D)$ and potassium $( \pm S D)$ in soil samples of closer $(C L)$ and further (FU) plots located along informal (width $<50 \mathrm{~cm}$ ) and formal (width $>150 \mathrm{~cm}$ ) tourist trails within the forest interior and forest edge sites. The statistical significance level is explained in Figure 2.

The mean percentage of plant cover damaged by trampling ranged from 0.1 to 3.1 and was significantly greater in CL than in FU plots; moreover, it did not differ between informal and formal tourist trails (Figure 8). The contribution of trampled plant cover did not differ between forest interior sites and forest edge sites in FU plots located along formal trails $(\mathrm{t}=0.36, \mathrm{df}=98, p=0.71)$ as well as in CL $(\mathrm{t}=0.83, \mathrm{df}=98, p=0.40)$ and FU $(\mathrm{t}=0.82, \mathrm{df}=98, p=0.41)$ plots located along informal trails. Only in $\mathrm{CL}(\mathrm{t}=-2.7, \mathrm{df}=98$, 
$p<0.01)$ plots located along formal trails was it much greater in forest edge sites than in forest interior sites.

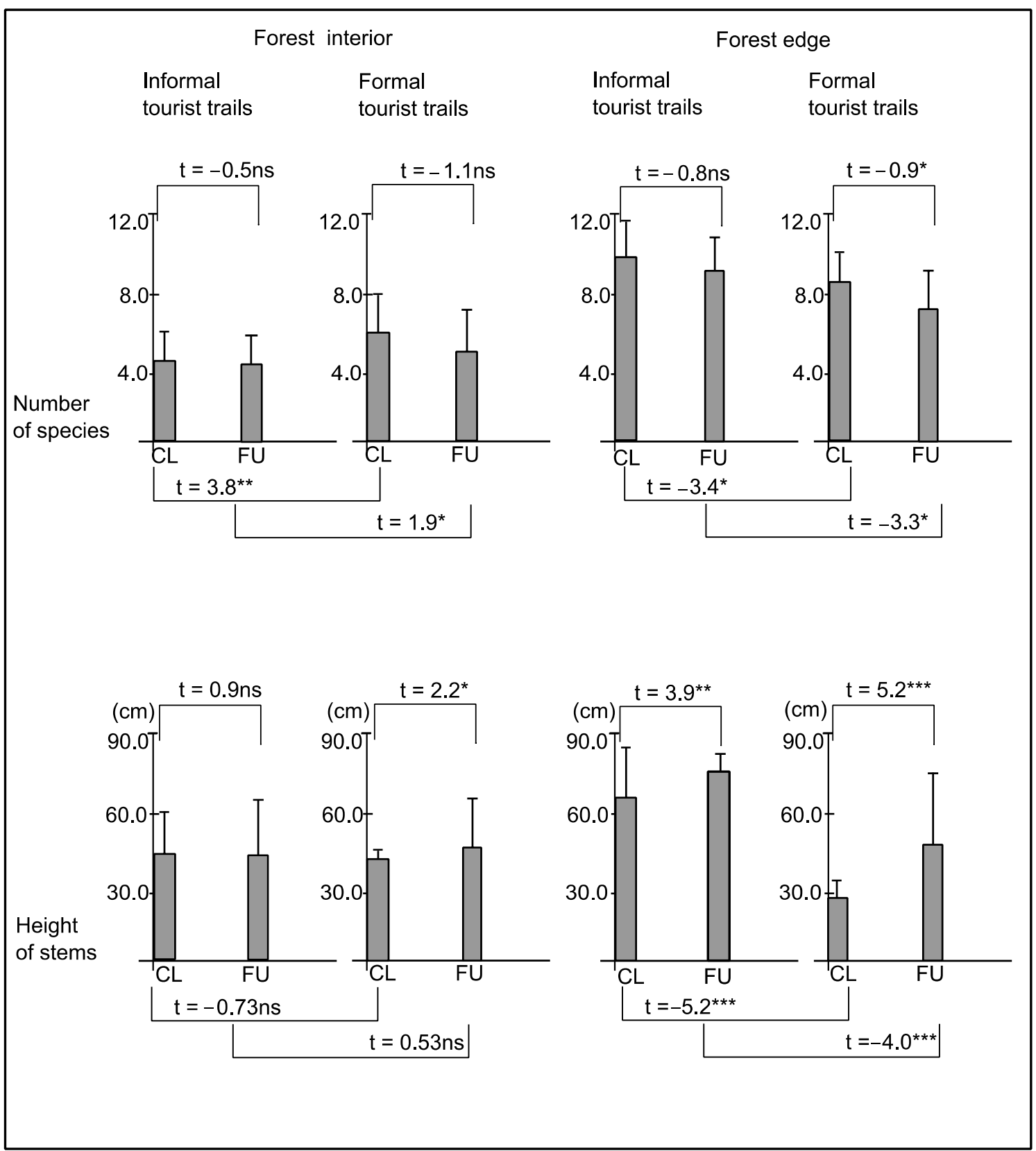

Figure 7. The mean values of number of species $( \pm S D)$ and height $(\mathrm{cm})$ of the tallest undergrowth plant $( \pm S D)$ in closer (CL) and further (FU) plots located along informal (width $<50 \mathrm{~cm}$ ) and formal (width $>150 \mathrm{~cm}$ ) tourist trails within the forest interior and forest edge sites. The statistical significance level is explained in Figure 2.

\subsection{The Characteristics of Species Groups}

In the majority of CL and FU plots, therophytes and hemicryptophytes were the most abundant species. Moreover, in forest interior sites, therophytes dominated along informal tourist trails. The cover-abundance of phanerophytes in the undergrowth was low; however, it was higher in FU than in CL plots (Figure 9). Therophytes dominated in forest interior sites, while hemicryptophytes dominated in forest edge sites. It was observed in $\mathrm{CL}\left(\chi^{2}=55.2, p<0.001, \mathrm{df}=5\right)$ and $\mathrm{FU}\left(\chi^{2}=78.6, p<0.001, \mathrm{df}=5\right)$ plots located along informal trails as well as in CL $\left(\chi^{2}=53.3, p<0.001, \mathrm{df}=3\right)$ and FU $\left(\chi^{2}=45.3, p<0.001\right.$, $\mathrm{df}=3$ ) plots located along formal tourist trails. 


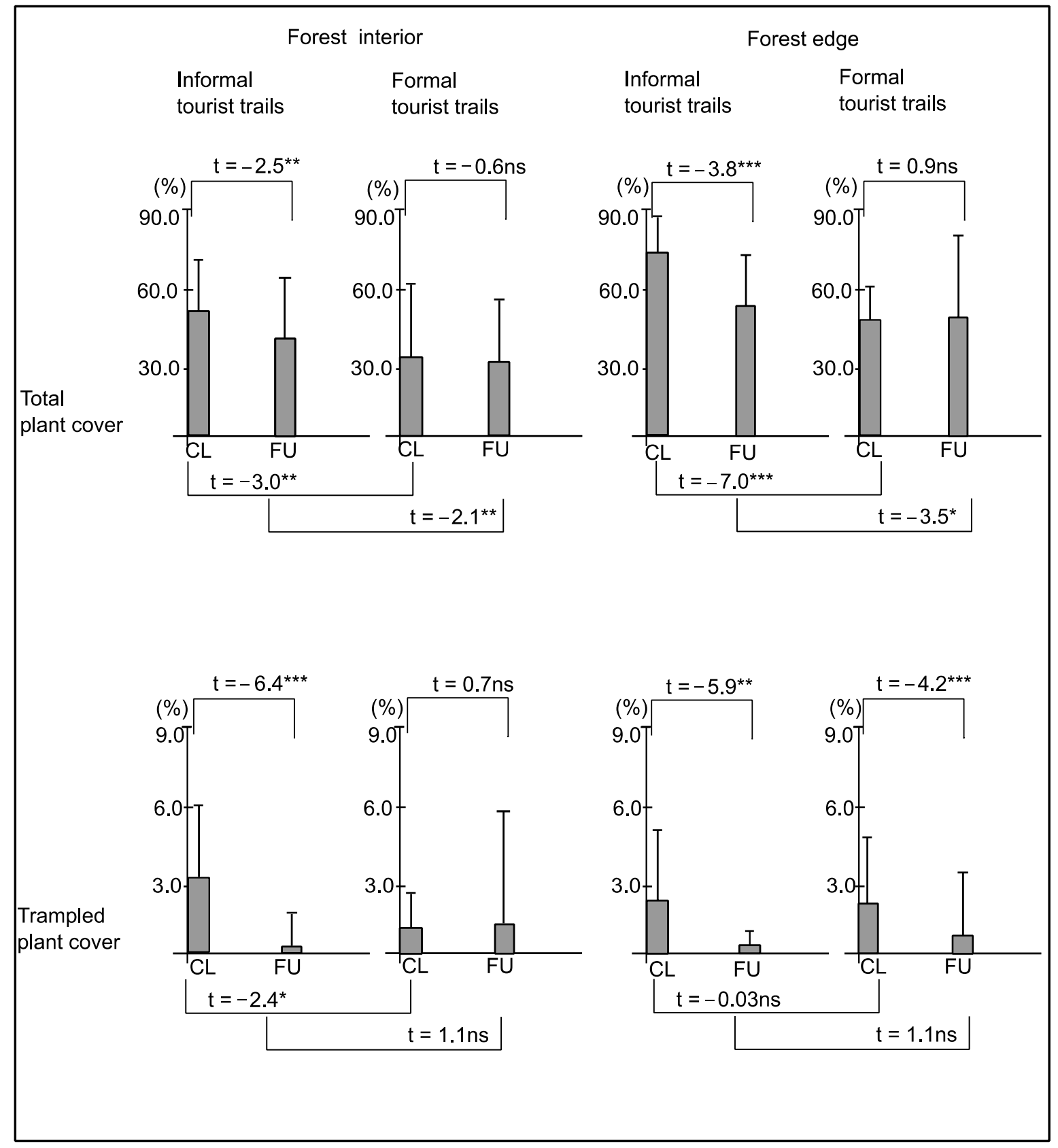

Figure 8. The mean values of total plant cover $( \pm S D)$ and the percentage of plant cover damaged by trampling in closer (CL) and further (FU) plots located along informal (width $<50 \mathrm{~cm}$ ) and formal (width $>150 \mathrm{~cm}$ ) tourist trails within the forest interior and forest edge sites. The statistical significance level is explained in Figure 2.

In CL and FU plots, the Allium dispersal mode dominated. Additionally, the Bidens and Cornus types were abundantly represented in plots located along formal tourist trails (Figure 10). Comparing the forest interior and forest edge sites, the Allium dispersal mode dominated, while the cover-abundance of species representing other modes differed significantly in CL $\left(\chi^{2}=121.2, p<0.001, \mathrm{df}=6\right)$ and $\mathrm{FU}\left(\chi^{2}=63.0, p<0.001, \mathrm{df}=6\right)$ plots located along informal trails as well as in CL $\left(\chi^{2}=59.9, p<0.001, \mathrm{df}=6\right)$ and FU $\left(\chi^{2}=66.0\right.$, $p<0.001, \mathrm{df}=6$ ) plots located along formal tourist trails.

Habitat affiliation differed substantially between forest interior sites (domination of forest and ruderal species) and forest edge sites (domination of grassland and meadow taxa). It was confirmed in CL $\left(\chi^{2}=12.8, p<0.001, \mathrm{df}=3\right)$ and FU $\left(\chi^{2}=22.3, p<0.001\right.$, $\mathrm{df}=3)$ plots located along informal tourist trails as well as in CL $\left(\chi^{2}=23.8, p<0.001, \mathrm{df}=3\right)$ 
and FU $\left(\chi^{2}=30.6, p<0.001, \mathrm{df}=3\right)$ plots located along formal tourist trails. The ruderal species dominated particularly in CL plots located along informal trails in forest interior sites (Figure 11).

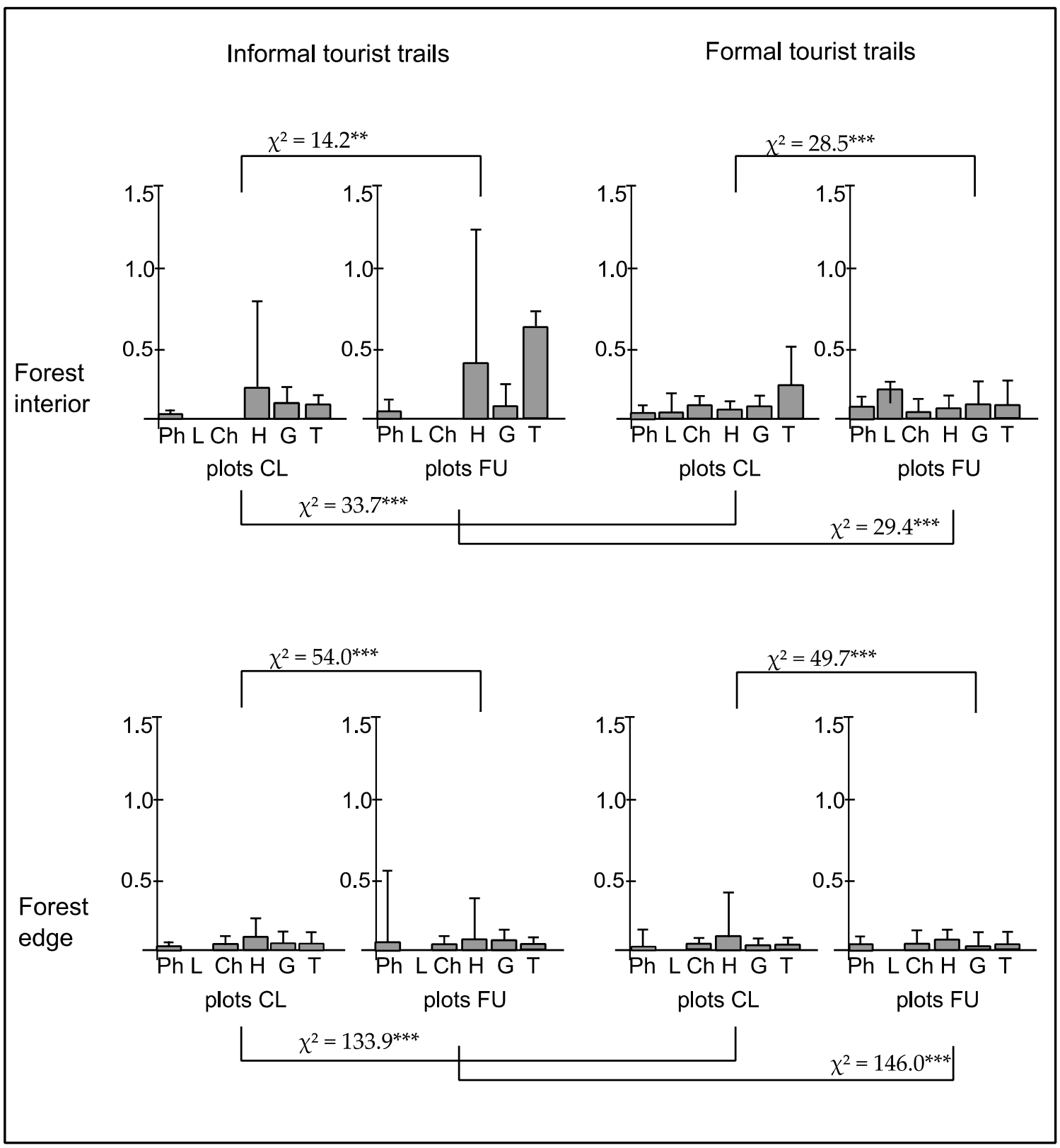

Figure 9. The mean cover-abundance degree of species $( \pm \mathrm{SD})$ representing phanerophytes (Ph), lianas (L), chamaephytes $(\mathrm{Ch})$, hemicryptophytes $(\mathrm{H})$, geophytes $(\mathrm{G})$, and therophytes $(\mathrm{T})$ per plot in closer $(\mathrm{CL})$ and further (FU) plots located along informal (width $<50 \mathrm{~cm}$ ) and formal (width $>150 \mathrm{~cm}$ ) tourist trails within the forest interior and forest edge sites. The statistical significance level is explained in Figure 2.

In study sites, there were only 14 alien species, including 9 invasive species (Appendix A, Table A1). However, the predominance of alien species in the cover-abundance of undergrowth was noticed in most of the plots (Figure 12). Comparing the forest interior and forest edge sites, the cover-abundance of alien species differed significantly in plots $C L$ $\left(\chi^{2}=6.8, p<0.01, \mathrm{df}=1\right)$ and $\mathrm{FU}\left(\chi^{2}=7.5, p<0.01, \mathrm{df}=1\right)$ located along informal tourist trails as well as in $\mathrm{CL}\left(\chi^{2}=9.5, p<0.01, \mathrm{df}=1\right)$ and FU $\left(\chi^{2}=12.7, p<0.001, \mathrm{df}=1\right)$ plots located along formal tourist trails. 


\section{Informal tourist trails}

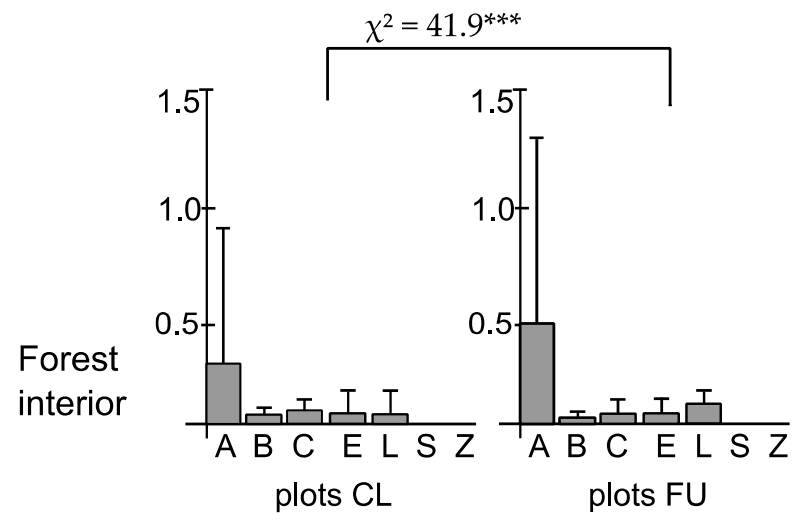

plots FU
Formal tourist trails

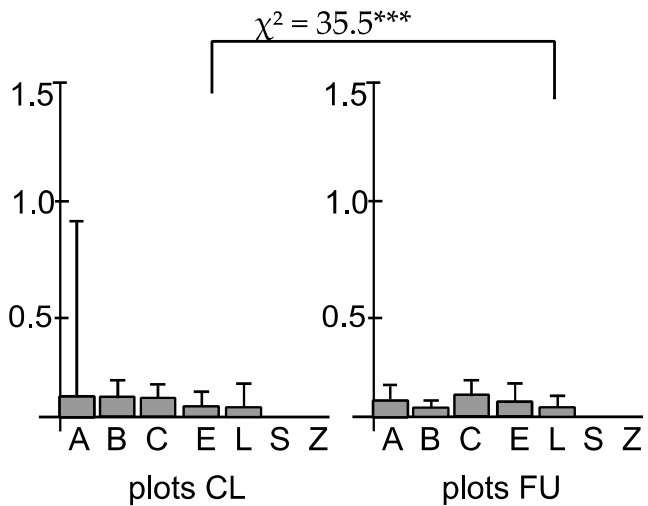

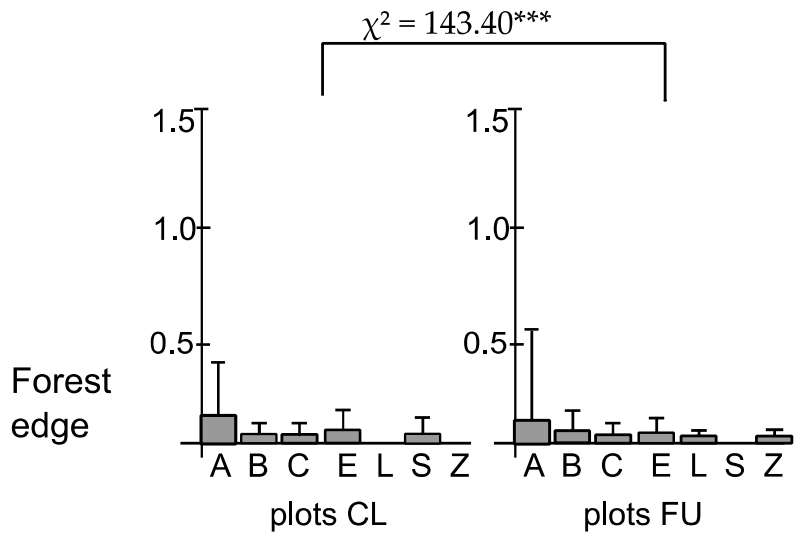

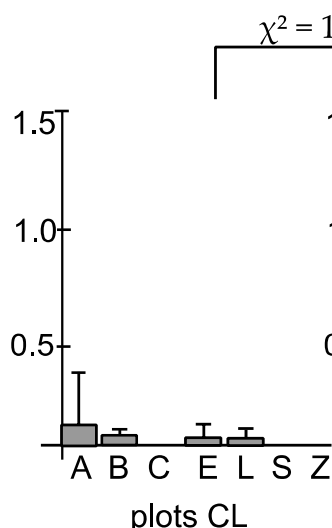

$\chi^{2}=45.0^{* * *}$

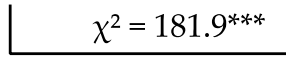

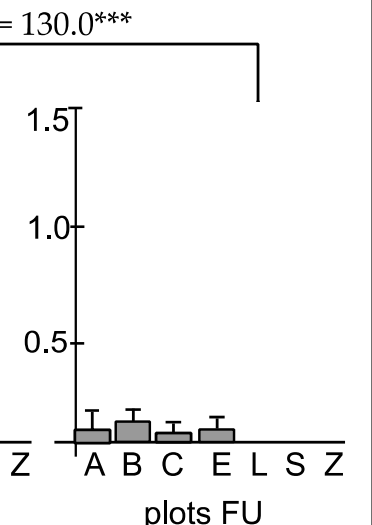

$\chi^{2}=93.0^{* * *}$

Figure 10. The mean cover-abundance degree of species $( \pm \mathrm{SD})$ representing Allium (A), Bidens (B), Cornus (C), Epilobium (E), Lycopodium (L), Sparganium (S) and Zea (Z) dispersal type per plot in closer (CL) and further (FU) plots located along informal (width $<50 \mathrm{~cm}$ ) and formal (width $>150 \mathrm{~cm}$ ) tourist trails within the forest interior and forest edge sites. The statistical significance level is explained in Figure 2. 


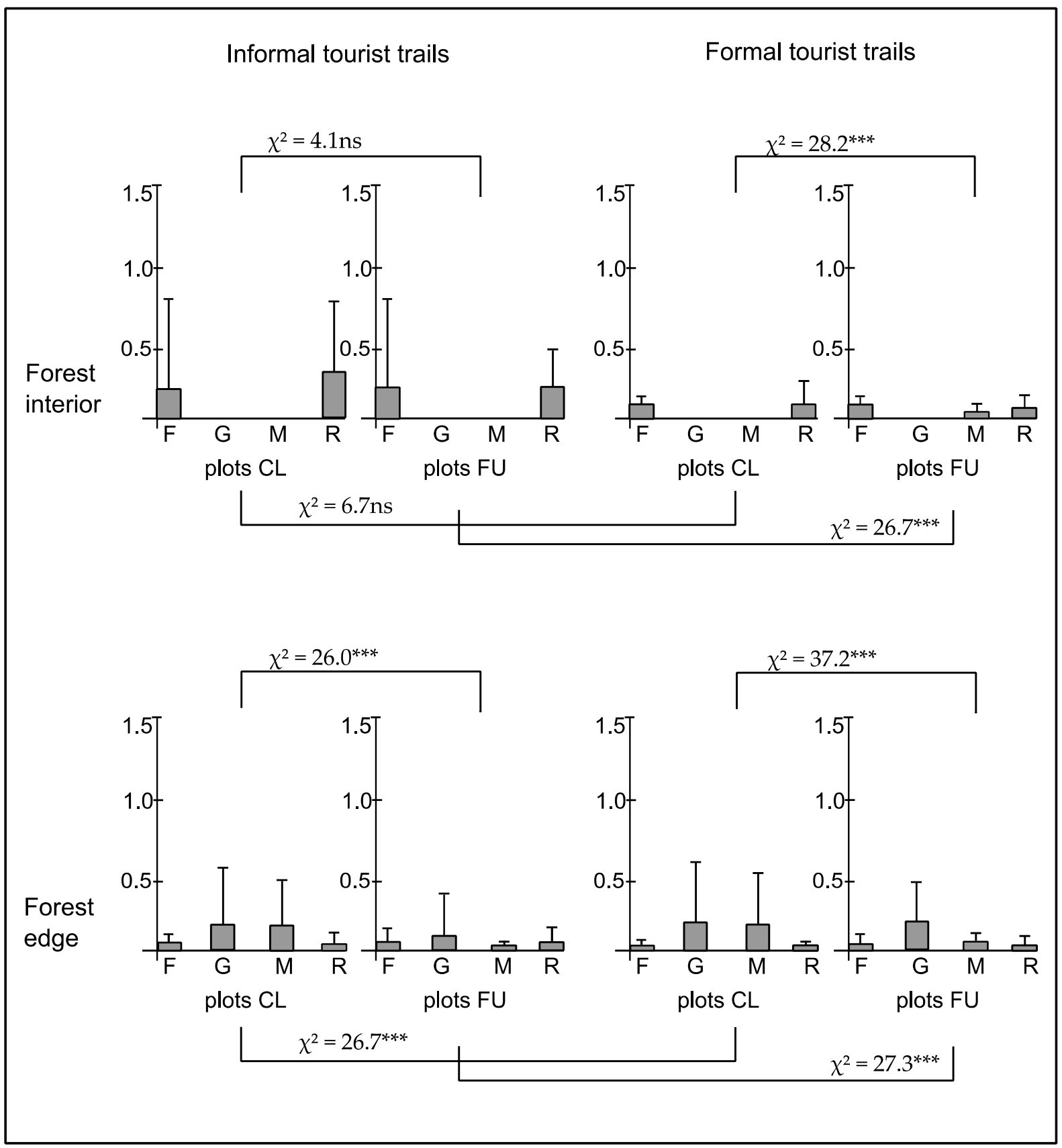

Figure 11. The mean cover-abundance degree of species $( \pm S D)$ affiliated with forest $(F)$, grassland $(G)$, meadow $(M)$ and ruderal (R) habitats per plot in closer (CL) and further (FU) plots located along informal (width $<50 \mathrm{~cm}$ ) and formal (width $>150 \mathrm{~cm}$ ) tourist trails within the forest interior and forest edge sites. The statistical significance level is explained in Figure 2. 


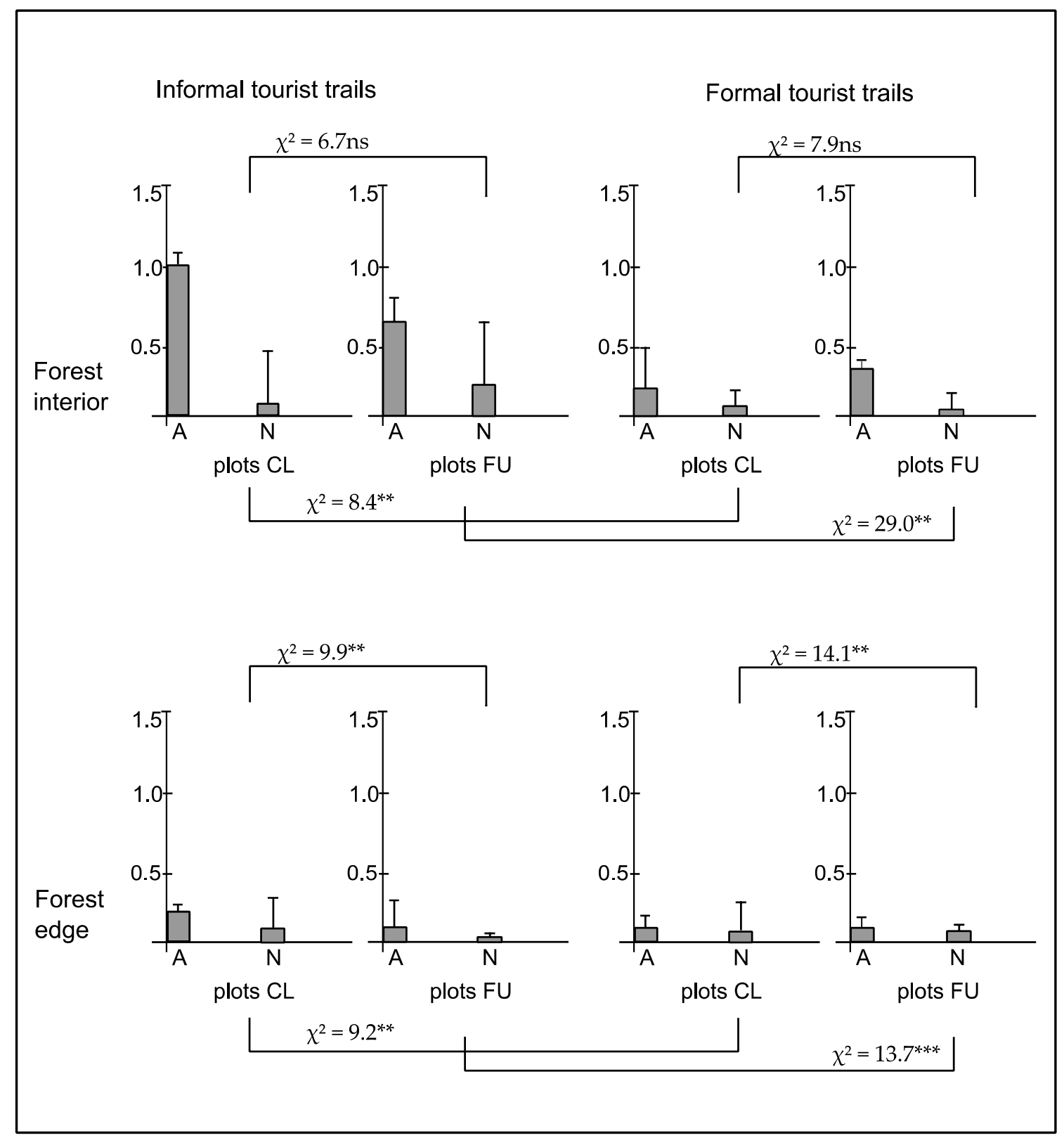

Figure 12. The mean cover-abundance degree of alien $(A)$ and native $(N)$ species $( \pm S D)$ per plot in closer (CL) and further (FU) plots located along informal (width $<50 \mathrm{~cm}$ ) and formal (width $>150 \mathrm{~cm}$ ) tourist trails within the forest interior and forest edge sites. The statistical significance level is explained in Figure 2.

\section{Discussion}

\subsection{The Effect of Informal Tourist Trails on Light Intensity and Soil Conditions}

In forests, the light intensity in the undergrowth depends on the cover of the understory and canopy layers [37] and references therein. For this reason, the light intensity is higher in the canopy gaps [38] as well as at the forest edges [39]. Informal trails are usually created by humans to take a shortcut, pass other trail users, avoid barriers such as muddy areas or fallen trees, view flora and fauna, explore nature, etc. [40] and references therein. Interestingly, tourist trails can increase the light intensity within forests by decreasing the cover-abundance of shrub and tree species. This effect is caused by regular trampling and other mechanical damage to woody plants (phanerophytes) occurring on tourist trails and their verges [40] and references therein. On intensively used trails, trampling may lead to the loss of vegetation [41]. In our study, the cover-abundance of young phanerophytes in 
the undergrowth layer was low in plots located close to the informal and formal tourist trails. Our results suggest that even in the close vicinity of the informal trails in the forestwhich are usually very narrow - the light intensity can be higher than in places situated far from these trails. Nevertheless, Roovers et al. [42] evidenced that the distance from footpaths in temperate deciduous forests does not affect light availability (measured by Ellenberg's light indicator values).

Informal tourist trails did not affect soil $\mathrm{pH}$, moisture, and content of ammonium nitrogen, nitrite, nitrate, phosphorus, and potassium in plots in both forest interior and forest edge sites. However, the soil in plots located further from formal pathways and the soil in plots located close to informal pathways were more alkaline in forest edge sites than in forest interior sites. The soil in plots located further from formal pathways was moister in forest edge sites than in forest interior sites. Moreover, the soil of plots located along informal and formal pathways contained more ammonium nitrogen, phosphorus, and potassium in forest interior sites than in forest edge sites. Our results correspond with the studies of several authors e.g., [43,44] who evidenced that the soil in forest clearings shows significantly lower potassium and phosphorous content than in forest plots, most likely due to leaching loss. Kooch et al. [45] proved that base cations' leaching potential increases with the expanding of canopy opening areas in mixed forests, and therefore the soil is poor in nutrient elements in large canopy gaps. Moreover, the authors pointed out that the leaching potential of soil nutrients increases with expanding canopy gaps and augmentation of water drainage and streamflow. Additionally, it is worth mentioning that Ellenberg's indicator values of nitrogen were significantly higher in coniferous forest interior than in forest edge stands in Lithuania [39]. Interesting results were also provided by Zhou et al. [46], who studied the effect of road width on roadside vegetation and soil conditions in forests in eastern China. The authors evidenced that the soil moisture increased from forest edges to the forest interiors along both wide and narrow roads, without significant differences. Moreover, the soil pH at the edge sites was significantly less acidic than that at the interior sites along the wide roads. The soil total nitrogen tended to increase from the road edge to the forest interior, without significant differences along the wide roads, while no effects of distance from the road on soil available phosphorus were found. The soil total nitrogen and soil available phosphorus did not change along narrow roads. According to Pankiw [40] and references therein, the removal of vegetation by trampling may lead to the rapid erosion of mineral soils, especially on slopes, and the erosion causes higher stress to plants because it reduces the water retention and nutrient accumulation abilities of the soil. Moreover, on tramped trails, the soil is more compacted, which reduces soil aeration and water infiltration, and there is less organic litter, which also affects some plants [40] and references therein. Litter protects deposited seeds against movement, drought, predation, and early germination [47] and references therein. Soil erosion occurs commonly on tourist trails, and it was observed during our study as well as in other studies concerning urban forests e.g., [48].

\subsection{The Effect of Informal Tourist Trails on Plant Cover Traits}

The creation and persistence of new informal trails in forest habitats depend on the intensity and frequency of disturbance by passing humans. The species richness decreases significantly in the place where the new trail is created, but this process can be rapidly and fully reversed when human activities are not allowed to continue [49]. However, the long use of informal trails by humans can cause different effects on species richness in forest areas. In our study, surprisingly, the species richness was higher in plots located close to the trails than in plots located further from the trails only in the case of formal tourist trails in the forest edge sites. In other cases, the distance from the tourist trails did not affect the number of species. Generally, human paths have a positive impact on plant richness [50]. One of the most important factors influencing species richness in forests is light availability [37]. Although the light intensity was higher in plots located close to tourist trails than in plots located further from the trails, species richness was similar 
despite the distance in forest interior sites. Similarly, the distance from tourist trails did not affect species richness in plots of informal trails in forest edge sites, though the light intensity was much higher in plots located close to the trails. Our results suggest that better light intensity does not always increase species richness in forests and that other factors can be involved. On the other hand, the higher number of species in plots of forest edge sites than in plots of forest interior sites can be explained by greater light availability, allowing the growth of light-demanding species. The higher species richness in the forest edge than in the forest interior has been repeatedly observed in temperate [51,52] and tropical forests [53,54], while in the boreal forest this trend is rather weak [55]. Moreover, the decrease in plant richness from forest edge to interior was also observed along narrow roads in various types of forests in eastern China [46].

The plants growing in plots located further from the tourist trails were taller, except for the plots of informal trails in forest interior sites, where the height of stems was similar. Plants growing close to the tourist trails experience more trampling and other mechanical factors than plants growing further from the trails, and therefore they are usually shorter $[40,56]$. In the forest interior and forest edge sites, the total plant cover was higher in plots located along informal tourist trails than in plots located along formal trails; however, there was no effect of distance on total plant cover in formal trails. Moreover, plant cover was higher in forest edge sites than in forest interior sites. Our results suggest that formal tourist trails have a more negative effect on adjacent plant cover than informal trails. The plant cover of undergrowth is strongly affected by light availability [37] and trampling e.g., [40,41,57]. According to Roovers et al. [58], dry forests dominated by oaks and birches are less sensitive to trampling than mesophilous forests dominated by elms. In our study, the plant cover damaged by trampling was higher in plots located close to the tourist trails than in plots located further from the trails, except for formal trails in forest interior sites. The plant cover damaged by trampling was similar in plots of informal and formal trails, except for the plots located close to the trails in forest interior sites. Moreover, the plant cover damaged by trampling was higher in plots located close to formal trails in forest edge sites than in forest interior sites.

It is obvious that plant cover experiences more mechanical damage in the vicinity of tourist trails $[40,56]$. Numerous authors have claimed that tourist dispersion might have a negative influence on vegetation, especially in trail verges e.g., [59]. Our results suggest that plant cover is more prone to destruction by trampling in the vicinity of formal tourist trails in forest edge sites than in forest interior sites. However, the grasses, which had a high cover-abundance in the forest edge sites, are considered the most tolerant and resilient plants to trampling [40] and references therein. It is also worth mentioning that many other species, such as Hypochoeris radicata L., Juncus tenuis Willd., Plantago major L., Sagina procumbens L., and Trifolium repens L., show considerable resistance to trampling, and they are commonly found along roadsides and pathways [34,60]. In contrast, some forest species, like Pteridium aquilinum (L.) Kuhn, show low resistance to trampling [61]. In the case of clonal plants occurring in the undergrowth, human trampling can trigger mechanical stress and reduction of sexual reproduction through damage to flowering stems and/or impact on the number and dimensions of leaves. This was observed in populations of Anemone nemorosa L. [62] and Mercurialis perennis L. [63]. Moreover, human trampling and soil digging by dogs accompanying humans can contribute to genet fragmentation and vegetative propagation of species creating thin and delicate connections between ramets such as Fragaria vesca L. [64], Maianthemum bifolium (L.) F.W. Schmidt [65], Mercurialis perennis [66], and Milium effusum L. [67].

\subsection{The Effect of Informal Tourist Trails on Species Groups}

The cover-abundance of life forms in undergrowth differed between the plots located along informal and formal tourist trails in the forest interior and forest edge sites. The cover-abundance of phanerophytes was higher in plots of forest interior sites than in forest edge sites. A similar result was presented by Avon et al. [68]. The plant cover in 
plots of forest interior sites was dominated by therophytes, whereas the plant cover in plots of forest edge sites was dominated by hemicryptophytes. According to Pescott and Stewart [41], vegetation dominated by hemicryptophytes and geophytes recovers from trampling to a greater extent than vegetation dominated by other life forms. On the other hand, the loss of phanerophytes by trampling may lead to better light conditions on the forest floor $[37,40,41]$. Our results suggest that the cover-abundance of therophytes and phanerophytes is negatively affected in the close vicinity of informal and formal tourist trails in forest interior sites.

In the forest interior and forest edge sites, the cover-abundance of species representing various dispersal modes differed between informal and formal tourist trails. However, in all plots the Allium mode dominated. Our results suggest that informal tourist trails enhance the cover-abundance of plants with the Allium dispersal mode in contrast to formal tourist trails, especially in forest interior sites. This can be explained by the fact that people who usethe trails facilitate the explosive seed dispersal of autochorous plants representing Allium mode by touching the plants. They can also create the gaps in plant cover that serve as safe sites for seedling recruitment [69]. Presumably, the substantial abundance of Impatiens parviflora DC. observed in our study was caused by the frequent use of trails by humans and the creation of gaps where the species can achieve a high seed germination rate [70]. Moreover, the considerable role of humans in facilitating dispersal of ballistic diaspores of species presenting considerable germination rates in forests was evidenced in the case of Geranium robertianum L. [71] and Oxalis acetosella L. [72]. The substantial share of the Bidens and Cornus dispersal modes, especially along formal trails, suggests the successful dissemination of diaspores by dogs accompanying visitors via fur and excreta [73]. At the same time, it is worth mentioning that the substantial occurrence of zoo chorous taxa along wide trails was also observed in calcareous grasslands in Kraków [56]. Moreover, Pickering and Mount [74] evidenced that people passing the formal tourist trails can disseminate diaspores of numerous species via clothing and equipment. The role of tourists as unintentional seed dispersal agents was also reviewed by Pickering and Mount [75].

The plots of forest interior sites were characterised by the dominance of forest and ruderal species in cover-abundance of undergrowth. On the other hand, the plots of forest edge sites were dominated by grassland and meadow species in cover-abundance of undergrowth. A wide ecological spectrum of species in plots located in forest edge sites suggests that the soil had a rich seed bank and there were suitable conditions for seedling recruitment. The increase of species richness in the soil seed bank and presence of taxa affiliated to various habitats in forest interior-forest edge gradient was previously observed by Devlaeminck et al. [76], among others. Furthermore, a lack of grassland species and only slight occurrence of meadow taxa in forest interior sites most likely was caused by unfavourable conditions for their seed germination (too much shade from trees and shrubs), which was observed inter alia in temperate deciduous forests $[77,78]$ as well as in subtropical and tropical forests [79]. Our results suggest that, in forest interior sites, the presence of formal tourist trails causes a higher reduction in cover-abundance of forest and ruderal species than does the presence of informal trails. This can be explained by the fact that the forest and ruderal species are less resistant to trampling than meadow and grassland species [40] and references therein.

According to Danielewicz et al. [80], 180 alien plant species have been found as naturalised in the Polish forests, and 20\% of them strongly affect the composition and structure of the forest communities. The number and cover of alien plants in urban forests can be influenced by various factors, such as canopy gaps, vegetation type, light, disturbance frequency, soil fertility, and moisture [81,82]. Interestingly, in the urban forests of Poznań, western Poland, the cover of alien plants was the highest in Salicetumalbae R.Tx. and the lowest in Carpinionbetuli Issl. em. Oberd. and Pinus sylvestris L. monocultures. Moreover, the light and the disturbance frequency were negatively correlated with the cover of alien species, whereas the soil fertility was positively correlated with the cover of 
alien species [82]. Although the number of alien species was much lower than the number of native species in the undergrowth of the Wolski Forest, alien species had much higher cover-abundance than the native ones. The cover-abundance of alien plants was higher in plots located close to informal tourist trails than in plots located further from these trails, in both forest interior and forest edge sites. In contrast, the cover-abundance of alien plants in plots located close to formal tourist trails was lower than in plots located further from the formal trails, especially in the forest interior sites. Our results suggest that the distance from informal and formal tourist trails may affect the cover-abundance of alien plant species differently. Alien plants growing near the formal trails seem to be more exposed to mechanical damage than alien plants growing near the informal trails. On the other hand, native plants seem to be more sensitive to damage than alien plants [40]. The area of the Wolski Forest has been increasingly occupied by invasive alien plants, as have other parts of Kraków [26,83]. During the study, we observed numerous individuals of Impatiens parviflora in forest interior sites as well as Solidago canadensis L. and S. gigantea Aiton in forest edge sites. These species are among the most common and most noxious invasive plants in Poland [84]. The increase in the abundance of invasive alien species in urban forests may lead to a loss of native species [48,81]. The creation of informal trails in forests carries the risk of introduction of new alien species and may lead to a better penetration of alien plants that have been already introduced to forest communities. Unfortunately, the diaspores of many alien plants can be easily dispersed by users of trails, allowing further spread and invasion $[40,85,86]$.

\section{Conclusions}

Vegetation in urban forests is constantly impacted by human activities. The creation of informal trails by citizens and tourists causes changes in soil conditions and leads to fragmentation of plant cover and loss of native species. The effect of informal trails on abiotic conditions and floristic composition of deciduous forest undergrowth may be different and may result both from the location in the forest interior and forest edge sites and the distance from the trail. The greater light intensity at ground level in close vicinity to tourist trails might be a consequence of mechanical damage of woody plants by passing people. The greater content of ammonium nitrogen, phosphorus, and potassium in forest interior sites might be related to the leaching of cations from sites situated on the forest edge. The number of species can be greater along informal tourist trails, particularly in forest edge sites where the light intensity is higher. In addition, the total plant cover can be greater close to informal tourist trails in the forest edge sites. The use of trails by citizens and tourists contributes to damage of plant cover by trampling and reduces the height of plants in sites located close to the trails. The predominance of therophytes along informal trails in the forest interior sites seems to be related to the ballistic dispersal of diaspores (Allium mode) of abundantly occurring species (e.g. Impatiens parviflora and Geranium robertianum) by passing people. The substantial share of the Bidens and Cornus dispersal modes - especially along formal trails—suggests the successful dissemination of diaspores by dogs accompanying visitors. The predominance of forest and ruderal taxa in the forest interior sites along formal and informal trails suggests the presence of unfavourable conditions for seed germination of meadow and grassland species. The distance from informal and formal tourist trails may affect the cover-abundance of alien plant species differently. Alienplants growing near the formal trails seem to be more exposed to mechanical damage than alien plants growing near the informal trails. The impact of informal and formal tourist trails on the diversity and abundance of native and alien plants in urban forests requires further research.

Author Contributions: K.K.-G.: conceptualization and methodology of research, project administration, field research, data analysis, manuscript preparation and correction. A.P.: field research, data analysis, manuscript preparation and correction. K.G.: field research, manuscript preparation and correction. All authors have read and agreed to the published version of the manuscript. 
Funding: This research received funding from the University of Physical Education in Krakówas part of statutory research (project number 244/BS/IT/2020).

Institutional Review Board Statement: Not applicable.

Informed Consent Statement: Not applicable.

Data Availability Statement: Not applicable.

Acknowledgments: The authors would like to thank Zbigniew GierałtEng. for his assistance in conducting the soil analysis and two anonymous reviewers for their comments and suggestions, which have been very helpful in improving the manuscript.

Conflicts of Interest: The authors declare no conflict of interest. The funder had no role in the design of the study, in the collection, analyses or interpretation of data, in the writing of the manuscript, or in the decision to publish the results.

\section{Appendix A}

Table A1. The characteristics of species found in the plant cover of the studied deciduous forest undergrowth regarding habitat affiliations according to Matuszkiewicz [34], life form and dispersal type according to the Database of the Czech flora and vegetationPladias [32], and origin and invasive statusaccording to the Alien species in Poland database [35] and references therein.

\begin{tabular}{|c|c|c|c|c|c|}
\hline No & Taxon & Habitat & Life Form & Dispersal Type & $\begin{array}{c}\text { Origin and } \\
\text { Invasive Status }\end{array}$ \\
\hline 1 & Acer platanoides L. & $\mathrm{F}$ & $\mathrm{PH}$ & Epilobium & $\mathrm{N}$ \\
\hline 2 & Acer pseudoplatanus L. & $\mathrm{F}$ & $\mathrm{PH}$ & Epilobium & $\mathrm{N}$ \\
\hline 3 & Achillea millefolium $\mathrm{L}$. & M & $\mathrm{H}$ & Allium & $\mathrm{N}$ \\
\hline 4 & Aegopodium podagraria L. & $\mathrm{F}$ & $\mathrm{H}$ & Allium & $\mathrm{N}$ \\
\hline 5 & Agrimonia eupatoria L. & G & $\mathrm{H}$ & Bidens & $\mathrm{N}$ \\
\hline 6 & Agrostis capillaris L. & G & $\mathrm{H}$ & Allium & $\mathrm{N}$ \\
\hline 7 & Ajuga reptans L. & $\mathrm{F}$ & $\mathrm{H}$ & Allium & $\mathrm{N}$ \\
\hline 8 & Alliaria petiolata (M. Bieb.) Cavara \& Grande & $\mathrm{R}$ & $\mathrm{H}$ & Allium & $\mathrm{N}$ \\
\hline 9 & Alopecurus pratensis L. & M & $\mathrm{H}$ & Allium & $\mathrm{N}$ \\
\hline 10 & Anemone nemorosa L. & $\mathrm{F}$ & G & Allium & $\mathrm{N}$ \\
\hline 11 & Anthriscus nitida (Wahlenb.) Hazsl. & M & $\mathrm{H}$ & Allium & $\mathrm{N}$ \\
\hline 12 & Arctium lappa L. & $\mathrm{R}$ & $\mathrm{H}$ & Bidens & $\mathrm{N}$ \\
\hline 13 & Armoracia rusticana P. Gaertn., B. Mey \& Scherb. & $\mathrm{R}$ & $\mathrm{H}$ & Zea & $\mathrm{A}$ \\
\hline 14 & Arrhenatherum elatius (L.) P. Beauv. ex J. Presl \& C. Presl & M & $\mathrm{H}$ & Allium & $\mathrm{N}$ \\
\hline 15 & Artemisia vulgaris L. & $\mathrm{R}$ & $\mathrm{H}$ & Allium & $\mathrm{N}$ \\
\hline 16 & Athyrium filix-femina (L.) Roth & $\mathrm{F}$ & $\mathrm{H}$ & Lycopodium & $\mathrm{N}$ \\
\hline 17 & Bellis perennis L. & M & $\mathrm{H}$ & Allium & $\mathrm{N}$ \\
\hline 18 & Bromus hordeaceus L. & M & $\mathrm{T}$ & Allium & $\mathrm{N}$ \\
\hline 19 & Calystegia sepium (L.) R. Br. & $\mathrm{R}$ & G & Allium & $\mathrm{N}$ \\
\hline 20 & Capsella bursa-pastoris (L.) Medik. & $\mathrm{R}$ & $\mathrm{T}$ & Allium & $\mathrm{A}$ \\
\hline 21 & Carex brizoides L. & $\mathrm{F}$ & $\mathrm{H}$ & Allium & $\mathrm{N}$ \\
\hline 22 & Carex hirta L. & M & $\mathrm{H}$ & Allium & $\mathrm{N}$ \\
\hline 23 & Carex leporina L. & M & $\mathrm{H}$ & Allium & $\mathrm{N}$ \\
\hline 24 & Carex pallescens L. & M & $\mathrm{H}$ & Allium & $\mathrm{N}$ \\
\hline 25 & Carex pilulifera $\mathrm{L}$. & G & $\mathrm{H}$ & Allium & $\mathrm{N}$ \\
\hline 26 & Carex sylvatica Huds. & $\mathrm{F}$ & $\mathrm{H}$ & Allium & $\mathrm{N}$ \\
\hline 27 & Carpinus betulus L. & $\mathrm{F}$ & $\mathrm{PH}$ & Epilobium & $\mathrm{N}$ \\
\hline 28 & Cerastium holosteoides Fr. emend. Hyl. & M & $\mathrm{H}$ & Allium & $\mathrm{N}$ \\
\hline 29 & Cerasus avium (L.) Moench & $\mathrm{F}$ & $\mathrm{PH}$ & Cornus & $\mathrm{N}$ \\
\hline 30 & Chaerophyllum aromaticum $\mathrm{L}$. & $\mathrm{R}$ & $\mathrm{H}$ & Allium & $\mathrm{N}$ \\
\hline 31 & Chaerophyllum temulum L. & $\mathrm{R}$ & $\mathrm{H}$ & Allium & $\mathrm{N}$ \\
\hline 32 & Circaea lutetiana L. & $\mathrm{F}$ & $\mathrm{G}$ & Bidens & $\mathrm{N}$ \\
\hline 33 & Cirsium arvense (L.) Scop. & $\mathrm{R}$ & G & Epilobium & $\mathrm{N}$ \\
\hline 34 & Clinopodium vulgare L. & $\mathrm{G}$ & $\mathrm{H}$ & Allium & $\mathrm{N}$ \\
\hline 35 & Convallaria majalis L. & $\mathrm{F}$ & G & Cornus & $\mathrm{N}$ \\
\hline
\end{tabular}


Table A1. Cont.

\begin{tabular}{|c|c|c|c|c|c|}
\hline No & Taxon & Habitat & Life Form & Dispersal Type & $\begin{array}{c}\text { Origin and } \\
\text { Invasive Status }\end{array}$ \\
\hline 36 & Convolvulus arvensis L. & $\mathrm{R}$ & G & Allium & $\mathrm{N}$ \\
\hline 37 & Corylus avellana L. & $\mathrm{F}$ & $\mathrm{PH}$ & Cornus & $\mathrm{N}$ \\
\hline 38 & Crepis biennis L. & M & $\mathrm{H}$ & Epilobium & $\mathrm{N}$ \\
\hline 39 & Crepis capillaris (L.) Wallr. & M & $\mathrm{T}$ & Epilobium & $\mathrm{N}$ \\
\hline 40 & Dactylis glomerata L. & M & $\mathrm{H}$ & Allium & $\mathrm{N}$ \\
\hline 41 & Daucus carota $\mathrm{L}$. & M & $\mathrm{H}$ & Bidens & $\mathrm{N}$ \\
\hline 42 & Dryopteris expansa (C. Presl) Fraser-Jenk. \& Jermy & $\mathrm{F}$ & $\mathrm{H}$ & Lycopodium & $\mathrm{N}$ \\
\hline 43 & Dryopteris filix-mas (L.) Schott & $\mathrm{F}$ & $\mathrm{H}$ & Lycopodium & $\mathrm{N}$ \\
\hline 44 & Dryopteris carthusiana (Vill.) H. P. Fuchs & $\mathrm{F}$ & $\mathrm{H}$ & Lycopodium & $\mathrm{N}$ \\
\hline 45 & Elymus repens (L.) Gould & $\mathrm{R}$ & G & Allium & $\mathrm{N}$ \\
\hline 46 & Epilobium montanum $\mathrm{L}$. & $\mathrm{R}$ & $\mathrm{H}$ & Epilobium & $\mathrm{N}$ \\
\hline 47 & Epilobium sp. & - & - & - & - \\
\hline 48 & Equisetum arvense $\mathrm{L}$. & $\mathrm{R}$ & G & Lycopodium & $\mathrm{N}$ \\
\hline 49 & Equisetum pratense Ehrh. & $\mathrm{F}$ & $\mathrm{G}$ & Lycopodium & $\mathrm{N}$ \\
\hline 50 & Erigeron annuus (L.) Pers. & $\mathrm{R}$ & $\mathrm{T}$ & Epilobium & A, I \\
\hline 51 & Erigeron canadensis L. & $\mathrm{R}$ & $\mathrm{T}$ & Epilobium & A, I \\
\hline 52 & Euonymus europaea L. & G & $\mathrm{PH}$ & Cornus & $\mathrm{N}$ \\
\hline 53 & Fagus sylvatica L. & $\mathrm{F}$ & $\mathrm{PH}$ & Cornus & $\mathrm{N}$ \\
\hline 54 & Festuca arundinacea Schreb. & M & $\mathrm{H}$ & Allium & $\mathrm{N}$ \\
\hline 55 & Festuca gigantea (L.) Vill. & $\mathrm{F}$ & $\mathrm{H}$ & Allium & $\mathrm{N}$ \\
\hline 56 & Festuca pratensis Huds. & M & $\mathrm{H}$ & Allium & $\mathrm{N}$ \\
\hline 57 & Festuca rubra L. & M & $\mathrm{H}$ & Allium & $\mathrm{N}$ \\
\hline 58 & Ficaria verna Huds. & $\mathrm{F}$ & $\mathrm{G}$ & Allium & $\mathrm{N}$ \\
\hline 59 & Fragaria vesca L. & $\mathrm{R}$ & $\mathrm{H}$ & Cornus & $\mathrm{N}$ \\
\hline 60 & Fraxinus excelsior $\mathrm{L}$. & $\mathrm{F}$ & $\mathrm{PH}$ & Epilobium & $\mathrm{N}$ \\
\hline 61 & Galeobdolon luteum Huds. & $\mathrm{F}$ & $\mathrm{CH}$ & Allium & $\mathrm{N}$ \\
\hline 62 & Galeopsis tetrahit L. & $\mathrm{R}$ & $\mathrm{T}$ & Allium & $\mathrm{N}$ \\
\hline 63 & Galium aparine L. & $\mathrm{R}$ & $\mathrm{T}$ & Bidens & $\mathrm{N}$ \\
\hline 64 & Galium mollugo L. & M & $\mathrm{H}$ & Allium & $\mathrm{N}$ \\
\hline 65 & Geranium pratense L. & M & $\mathrm{H}$ & Allium & $\mathrm{N}$ \\
\hline 66 & Geranium robertianum $\mathrm{L}$. & $\mathrm{R}$ & $\mathrm{T}$ & Allium & $\mathrm{N}$ \\
\hline 67 & Geum urbanum L. & $\mathrm{R}$ & $\mathrm{H}$ & Bidens & $\mathrm{N}$ \\
\hline 68 & Glechoma hederacea L. & $\mathrm{R}$ & $\mathrm{H}$ & Allium & $\mathrm{N}$ \\
\hline 69 & Gnaphalium sylvaticum L. & $\mathrm{R}$ & $\mathrm{H}$ & Epilobium & $\mathrm{N}$ \\
\hline 70 & Hedera helix L. & $\mathrm{F}$ & $\mathrm{L}$ & Cornus & $\mathrm{N}$ \\
\hline 71 & Heracleum sphondylium L. & M & $\mathrm{H}$ & Allium & $\mathrm{N}$ \\
\hline 72 & Holcus lanatus L. & M & $\mathrm{H}$ & Allium & $\mathrm{N}$ \\
\hline 73 & Holcus mollis L. & $\mathrm{F}$ & G & Allium & $\mathrm{N}$ \\
\hline 74 & Hypericum humifusum L. & $\mathrm{R}$ & $\mathrm{H}$ & Allium & $\mathrm{N}$ \\
\hline 75 & Hypericum perforatum $\mathrm{L}$. & $\mathrm{R}$ & $\mathrm{H}$ & Allium & $\mathrm{N}$ \\
\hline 76 & Hypochaeris radicata $\mathrm{L}$. & G & $\mathrm{H}$ & Epilobium & $\mathrm{N}$ \\
\hline 77 & Impatiens parviflora DC. & $\mathrm{R}$ & $\mathrm{T}$ & Allium & A, I \\
\hline 78 & Juncus effusus L. & M & $\mathrm{H}$ & Sparganium & $\mathrm{N}$ \\
\hline 79 & Juncus tenuis Willd. & M & $\mathrm{H}$ & Allium & A, I \\
\hline 80 & Lapsana communis L. & $\mathrm{R}$ & $\mathrm{T}$ & Allium & $\mathrm{N}$ \\
\hline 81 & Leontodon autumnalis L. & M & $\mathrm{H}$ & Epilobium & $\mathrm{N}$ \\
\hline 82 & Leontodon hispidus L. & M & $\mathrm{H}$ & Epilobium & $\mathrm{N}$ \\
\hline 83 & Lolium multiflorum Lam. & - & $\mathrm{T}$ & Allium & A, I \\
\hline 84 & Lolium perenne $\mathrm{L}$. & M & $\mathrm{H}$ & Allium & $\mathrm{N}$ \\
\hline 85 & Luzula pilosa (L.) Willd. & $\mathrm{F}$ & $\mathrm{H}$ & Allium & $\mathrm{N}$ \\
\hline 86 & Lycopus europaeus L. & $\mathrm{F}$ & $\mathrm{H}$ & Sparganium & $\mathrm{N}$ \\
\hline 87 & Lysimachia nummularia L. & M & $\mathrm{H}$ & Allium & $\mathrm{N}$ \\
\hline 88 & Lysimachia vulgaris L. & M & $\mathrm{H}$ & Allium & $\mathrm{N}$ \\
\hline 89 & Maianthemum bifolium (L.) F. W. Schmidt & $\mathrm{F}$ & G & Cornus & $\mathrm{N}$ \\
\hline 90 & Malus domestica Borkh. & - & $\mathrm{PH}$ & Cornus & A \\
\hline 91 & Malva sylvestris L. & $\mathrm{F}$ & $\mathrm{H}$ & Allium & $\mathrm{A}$ \\
\hline 92 & Mercurialis perennis L. & $\mathrm{F}$ & $\mathrm{H}$ & Allium & $\mathrm{N}$ \\
\hline
\end{tabular}


Table A1. Cont.

\begin{tabular}{|c|c|c|c|c|c|}
\hline No & Taxon & Habitat & Life Form & Dispersal Type & $\begin{array}{c}\text { Origin and } \\
\text { Invasive Status }\end{array}$ \\
\hline 93 & Milium effusum L. & $\mathrm{F}$ & $\mathrm{H}$ & Allium & $\mathrm{N}$ \\
\hline 94 & Moehringia trinervia (L.) Clairv. & $\mathrm{R}$ & $\mathrm{H}$ & Allium & $\mathrm{N}$ \\
\hline 95 & Mycelis muralis (L.) Dumort. & $\mathrm{R}$ & $\mathrm{H}$ & Epilobium & $\mathrm{N}$ \\
\hline 96 & Myosoton aquaticum (L.) Moench & $\mathrm{R}$ & $\mathrm{H}$ & Allium & $\mathrm{N}$ \\
\hline 97 & Oxalis acetosella $\mathrm{L}$. & $\mathrm{F}$ & G & Allium & $\mathrm{N}$ \\
\hline 98 & Oxalis fontana Bunge & $\mathrm{R}$ & $\mathrm{T}$ & Allium & A, I \\
\hline 99 & Padus avium Mill. & $\mathrm{F}$ & $\mathrm{PH}$ & Cornus & $\mathrm{N}$ \\
\hline 100 & Phleum pratense $\mathrm{L}$. & M & $\mathrm{H}$ & Allium & $\mathrm{N}$ \\
\hline 101 & Plantago lanceolata L. & M & $\mathrm{H}$ & Allium & $\mathrm{N}$ \\
\hline 102 & Plantago major L. & M & $\mathrm{H}$ & Allium & $\mathrm{N}$ \\
\hline 103 & Poa annua L. & M & $\mathrm{H}$ & Allium & $\mathrm{N}$ \\
\hline 104 & Poa compressa L. & $\mathrm{R}$ & $\mathrm{H}$ & Allium & $\mathrm{N}$ \\
\hline 105 & Poa palustris L. & M & $\mathrm{H}$ & Allium & $\mathrm{N}$ \\
\hline 106 & Poa pratensis L. & M & $\mathrm{H}$ & Allium & $\mathrm{N}$ \\
\hline 107 & Poa trivialis $\mathrm{L}$. & M & $\mathrm{H}$ & Allium & $\mathrm{N}$ \\
\hline 108 & Polygonatum multiflorum (L.) All. & $\mathrm{F}$ & G & Cornus & $\mathrm{N}$ \\
\hline 109 & Polygonum aviculare L. & $\mathrm{R}$ & $\mathrm{T}$ & Allium & $\mathrm{N}$ \\
\hline 110 & Polygonum mite Schrank & $\mathrm{R}$ & $\mathrm{T}$ & Sparganium & $\mathrm{N}$ \\
\hline 111 & Populus tremula L. & $\mathrm{R}$ & $\mathrm{PH}$ & Epilobium & $\mathrm{N}$ \\
\hline 112 & Potentilla anserina $\mathrm{L}$. & G & $\mathrm{H}$ & Allium & $\mathrm{N}$ \\
\hline 113 & Potentilla erecta (L.) Raeusch. & G & $\mathrm{H}$ & Allium & $\mathrm{N}$ \\
\hline 114 & Potentilla reptans $\mathrm{L}$. & M & $\mathrm{H}$ & Allium & $\mathrm{N}$ \\
\hline 115 & Prunella vulgaris $\mathrm{L}$. & M & $\mathrm{H}$ & Allium & $\mathrm{N}$ \\
\hline 116 & Prunus spinosa L. & G & $\mathrm{PH}$ & Allium & $\mathrm{N}$ \\
\hline 117 & Pteridium aquilinum (L.) Kuhn & $\mathrm{F}$ & G & Lycopodium & $\mathrm{N}$ \\
\hline 118 & Pulmonaria obscura Dumort. & $\mathrm{F}$ & $\mathrm{H}$ & Allium & $\mathrm{N}$ \\
\hline 119 & Quercus petraea (Matt.) Liebl. & $\mathrm{F}$ & $\mathrm{PH}$ & Cornus & $\mathrm{N}$ \\
\hline 120 & Quercus rubra L. & $\mathrm{F}$ & $\mathrm{PH}$ & Cornus & A, I \\
\hline 121 & Ranunculus acris L. & M & $\mathrm{H}$ & Allium & $\mathrm{N}$ \\
\hline 122 & Ranunculus lanuginosus L. & $\mathrm{F}$ & $\mathrm{H}$ & Allium & $\mathrm{N}$ \\
\hline 123 & Ranunculus repens L. & M & $\mathrm{H}$ & Allium & $\mathrm{N}$ \\
\hline 124 & Ribes sp. & - & - & - & - \\
\hline 125 & Ribes spicatum E. Robson & $\mathrm{F}$ & $\mathrm{PH}$ & Cornus & $\mathrm{N}$ \\
\hline 126 & Ribes uva-crispa L. & - & $\mathrm{PH}$ & Cornus & $\mathrm{N}$ \\
\hline 127 & Rubus idaeus L. & $\mathrm{R}$ & $\mathrm{PH}$ & Cornus & $\mathrm{N}$ \\
\hline 128 & Rubus sp. & - & - & - & - \\
\hline 129 & Rumex obtusifolius L. & $\mathrm{R}$ & $\mathrm{H}$ & Allium & $\mathrm{N}$ \\
\hline 130 & Sagina procumbens L. & M & $\mathrm{H}$ & Allium & $\mathrm{N}$ \\
\hline 131 & Sambucus nigra L. & $\mathrm{R}$ & $\mathrm{PH}$ & Cornus & $\mathrm{N}$ \\
\hline 132 & Sanicula europaea L. & $\mathrm{F}$ & $\mathrm{H}$ & Bidens & $\mathrm{N}$ \\
\hline 133 & Scrophularia nodosa L. & $\mathrm{F}$ & $\mathrm{H}$ & Allium & $\mathrm{N}$ \\
\hline 134 & Solidago canadensis L. & $\mathrm{R}$ & $\mathrm{H}$ & Epilobium & A, I \\
\hline 135 & Solidago gigantea Aiton & $\mathrm{R}$ & $\mathrm{H}$ & Epilobium & A, I \\
\hline 136 & Stachys palustris L. & M & G & Allium & $\mathrm{N}$ \\
\hline 137 & Stachys sylvatica L. & $\mathrm{F}$ & $\mathrm{H}$ & Allium & $\mathrm{N}$ \\
\hline 138 & Stellaria graminea $\mathrm{L}$. & M & $\mathrm{H}$ & Allium & $\mathrm{N}$ \\
\hline 139 & Stellaria holostea L. & $\mathrm{F}$ & $\mathrm{CH}$ & Allium & $\mathrm{N}$ \\
\hline 140 & Stellaria media (L.) Vill. & $\mathrm{R}$ & $\mathrm{T}$ & Allium & $\mathrm{N}$ \\
\hline 141 & Symphytum officinale L. & $\mathrm{R}$ & $\mathrm{H}$ & Allium & $\mathrm{N}$ \\
\hline 142 & Taraxacum officinale F. H. Wigg. & M & $\mathrm{H}$ & Epilobium & $\mathrm{N}$ \\
\hline 143 & Tilia cordata Mill. & $\mathrm{F}$ & $\mathrm{PH}$ & Epilobium & $\mathrm{N}$ \\
\hline 144 & Tilia platyphyllos Scop. & $\mathrm{F}$ & $\mathrm{PH}$ & Epilobium & $\mathrm{N}$ \\
\hline 145 & Torilis japonica (Houtt.) DC. & $\mathrm{R}$ & $\mathrm{T}$ & Bidens & $\mathrm{N}$ \\
\hline 146 & Trifolium pratense L. & M & $\mathrm{H}$ & Allium & $\mathrm{N}$ \\
\hline 147 & Trifolium repens L. & M & $\mathrm{H}$ & Allium & $\mathrm{N}$ \\
\hline 148 & Tussilago farfara $\mathrm{L}$. & $\mathrm{R}$ & G & Epilobium & $\mathrm{N}$ \\
\hline
\end{tabular}


Table A1. Cont.

\begin{tabular}{|c|c|c|c|c|c|}
\hline No & Taxon & Habitat & Life Form & Dispersal Type & $\begin{array}{c}\text { Origin and } \\
\text { Invasive Status }\end{array}$ \\
\hline 149 & Urtica dioica $\mathrm{L}$. & $\mathrm{R}$ & $\mathrm{H}$ & Allium & $\mathrm{N}$ \\
\hline 150 & Veronica arvensis L. & $\mathrm{R}$ & $\mathrm{T}$ & Allium & A \\
\hline 151 & Veronica chamaedrys L. & G & $\mathrm{H}$ & Allium & $\mathrm{N}$ \\
\hline 152 & Veronica officinalis L. & G & $\mathrm{CH}$ & Allium & $\mathrm{N}$ \\
\hline 153 & Veronica serpyllifolia L. & $\mathrm{R}$ & $\mathrm{H}$ & Allium & $\mathrm{N}$ \\
\hline 154 & Viburnum opulus L. & $\mathrm{F}$ & $\mathrm{PH}$ & Cornus & $\mathrm{N}$ \\
\hline 155 & Vicia cracca L. & M & $\mathrm{H}$ & Allium & $\mathrm{N}$ \\
\hline 156 & Vicia sepium $\mathrm{L}$. & G & $\mathrm{H}$ & Allium & $\mathrm{N}$ \\
\hline 157 & Viola reichenbachiana Jord. ex Boreau & $\mathrm{F}$ & $\mathrm{H}$ & Allium & $\mathrm{N}$ \\
\hline 158 & Viola riviniana $\mathrm{Rchb}$. & $\mathrm{F}$ & $\mathrm{H}$ & Allium & $\mathrm{N}$ \\
\hline
\end{tabular}

Abbreviations. Habitat-F: forest taxon, G: grassland taxon, M: meadow taxon, R: ruderal taxon; Life form—PH: phanerophyte, CH: chamaephyte, H: hemicryptophyte, G: geophyte, L: liana, T: therophyte; Originand invasive status- $\mathrm{N}$ : native taxon, A: alien taxon, I: invasive taxon in Poland.

\section{References}

1. Jalinik, M. Forest areas stimulating the development of tourism. Ekonomiai Środowisko 2016, 3, 313-323.

2. Chudy, J.G. Urban forest management as an alternative to the development of local tourism in the context of social expectations. Studiai Materiaty CEPL w Rogowie 2017, 50, 194-303.

3. Janeczko, E.; Woźnicka, M. Development of urban forest recreation of Warsaw in the context of the needs and expectations of the residents of the capital. Studiai Materiały Centrum Edukacji Przyrodniczo-Leśnej 2009, 11, 131-139.

4. Deng, J.; Gazal, K.A.; Pierskalla, C.; McNeel, J. Linking Urban Forests and Urban Tourism: A Case of Savannah, Georgia. Tour. Anal. 2010, 15, 167-181. [CrossRef]

5. Wajchman, S. Urban forests and recreational development of the city of Poznan. Studiai Materiaty CEPL W Rogowie 2013, 34, 119-126.

6. Czubaszek, R.; Wysocka-Czubaszek, A.; Bartnik, I. Usefulness of urban and suburban forests in Białystok for recreation. Studia Miejskie 2014, 16, 87-99. [CrossRef]

7. Vakhlamova, T.; Rusterholz, H.P.; Kamkin, V.; Baur, B. Recreational use of urban and suburban forests affects plant diversity in a Western Siberian city. Urban For. Urban Green 2016, 17, 92-103. [CrossRef]

8. Cetin, M.; Sevik, H.; Canturk, U.; Cakir, C. Evaluation of the recreational potential of Kutahya urban forest. Fresenius Environ. Bull. 2018, 27, 2629-2634.

9. Chen, B.; Qiu, Z. Recreational use of urban forest parks-A case study in Fuzhou National Forest Park, China. J. For. Res. 2018, 23, 183-189. [CrossRef]

10. Zhao, Q.; Tang, H.H.; Gao, C.J.; Wei, Y.H. Evaluation of urban forest landscape health: A case study of the Nanguo Peach Garden, China. iForest-Biogeosci. For. 2020, 13, 175-184. [CrossRef]

11. Fadila, L.; Mohamed, B.; Alessandro, P. Social Demand for Ecosystem Services Provided by Peri-Urban Forests: The Case Study of the Tlemcen Forest (Algeria). J. Environ. Account. Manag. 2021, 9, 19-29. [CrossRef]

12. Referowska-Chodak, E. Pressures and threats to nature related to human activities in European urban and suburban Forests. Forests 2019, 10, 765. [CrossRef]

13. Malmivaara, M.; Löfström, I.; Vanha-Majamaa, I. Anthropogenic effects on understorey vegetation in Myrtillus type urban forests in southern Finland. Silva Fenn. 2002, 36, 367-381. [CrossRef]

14. Hamberg, L.; Lehvävirta, S.; Minna, M.L.; Rita, H.; Kotze, D.J. The effects of habitat edges and trampling on understorey vegetation in urban forests in Helsinki, Finland. Appl. Veg. Sci. 2008, 11, 83-98. [CrossRef]

15. Skłodowski, J.W.; Bartosz, S.; Dul, Ł.; Grzybek, D.; Jankowski, S.; Kajetanem, M.; Kalisz, P.; Korenkiewicz, U.; Mazur, G.; Myszek, J.; et al. An attempt to assess the effect of tourist trail width on adjacent forest environment. Sylwan 2009, 153, 699-709.

16. Zdanowicz, E.; Skłodkowski, S. Evaluation of changes in environment around recreational routes on the example of Bielański Forest Reserve in Warsaw. Studiai Materiaty CEPL W Rogowie 2013, 37, 348-355.

17. Ballantyne, M.; Pickering, C.M. Differences in the impacts of formal and informal recreational trails on urban forest loss and tree structure. J. Environ. Manag. 2015, 159, 94-105. [CrossRef] [PubMed]

18. Ballantyne, M.; Treby, D.L.; Quarmby, J.; Pickering, C.M. Comparing the impacts of different types of recreational trails on grey box grassy-woodland vegetation: Lessons for conservation and management. Aust. J. Bot. 2016, 64, 246-259. [CrossRef]

19. Malmivaara-Lämsä, M.; Hamberg, L.; Haapamäki, E.; Liski, J.; Kotze, D.J.; Lehvävirta, S.; Frtize, H. Edge effects and trampling in boreal urban forest fragments-impacts on the soil microbial community. Soil Biol. Biochem. 2008, 40, 1612-1621. [CrossRef]

20. Ballantyne, M.; Gudes, O.; Pickering, C.M. Recreational trails are an important cause of fragmentation in endangered urban forests: A case-study from Australia. Landsc. Urban Plan. 2014, 130, 112-124. [CrossRef] 
21. Ballantine, M.; Pickering, C.M. The impacts of trail infrastructure on vegetation and soils: Current literature and future directions. J. Environ. Manag. 2015, 164, 53-64. [CrossRef]

22. Skotnicki, J. Las Wolski; Studio Promocji i Reklamy TARGET: Kraków, Poland, 2000; p. 112.

23. Urząd, M.K.; Biuro, P.P.; Odział, P.P.; Pracownia, U. Miejscowy plan zagospodarowania przestrzennego "Las Wolski". Prognoza oddziaływania na środowisko; Urząd Miasta Krakowa: Kraków, Poland, 2008; aktualizacja-kwiecień 2009.

24. Banach, D.; Skrzypek, A. Problemy gospodarki leśnej w Lasku Wolskim. Przestrzeń-Urbanistyka-Architektura 2018,2 , 111-121.

25. Matuszko, D.; Piotrowicz, K. Cechy klimatu miasta a klimat Krakowa. In Miasto w Badaniach Geografów; Trzepacz, P., WięcławMichniewska, J., Brzosko-Sermak, A., Kołoś, A., Eds.; Instytut Geografii i Gospodarki Przestrzennej Uniwersytetu Jagiellońskiego: Kraków, Poland, 2015; Volume 12015, p. 221.

26. Dubiel, E. Aktualny stan roślinności Lasu Wolskiego-Miejskiego Parku w Krakowie. Chrońmy Przyr. Ojcz. 1971, $27,18-26$.

27. Kijas, Z.J.; Jarkiewicz, K.; Mróz, W.; Tadel, A. Las Wolski. In Skarby Przyrody i Kultury Krakowai i Okolic. Ekologiczne Ścieżki Edukacyjne; Grzegorczyk, M., Perzanowska, J., Eds.; WAM Publisher: Krakow, Poland, 2005; pp. 85-126.

28. Zygmunt, R.; Banaś, J.; Zięba, S. Urban forestsstability on the example of "Las Wolski" in Cracow. Studiai Materiały CEPL w Rogowie 2014, 16, 110-117.

29. Csapodý, V. Keimlingsbestimmungsbuch der Dikotyledonen; Akademiai Kiado: Budapeszt, Hungary, 1968 ; p. 286.

30. Muller, F.M. Seedlings of the North-Western European Lowland. A Flora of Seedlings, 1st ed.; Springer: Wageningen, The Netherlands, 1978; p. 653.

31. Braun-Blanquet, J. Pflanzensoziologie, Grundzüge der Vegetationskunde, 3rd ed.; Springer: Berlin, Germany, $1964 ;$ p. 631.

32. Pladias. Database of the Czech Flora and Vegetation. 2014. Available online: http:/ / www.pladias.org (accessed on 7 February 2021).

33. Sádlo, J.; Chytrý, M.; Pergl, J.; Pyšek, P. Plant dispersal strategies: A new classification based on the multiple dispersal modes of individual species. Preslia 2018, 90, 1-22. [CrossRef]

34. Matuszkiewicz, W.A. Guide for Identification of Polish Plant Communities; Polish Scientific Publishers PWN: Warsaw, Poland, 2017; p. 536.

35. Alien Species in Poland. Available online: http://www.iop.krakow.pl/ias/species (accessed on 7 February 2020).

36. Preacher, K. Calculation for the Chi-Square Test: An Interactive Calculation Tool for Chi-Square Tests of Goodness of Fit and Independence. 2001. Available online: http:/ / quantpsy.org (accessed on 7 February 2021).

37. Dormann, C.F.; Bagnara, M.; Boch, S.; Hinderling, J.; Janeiro-Otero, A.; Schäfer, D.; Schall, P.; Hartig, F. Plant species richness increases with light availability, but not variability, in temperate forests understorey. BMC Ecol. 2020, 20, 43. [CrossRef]

38. Gálhidy, L.; Mihók, B.; Hagyó, A.; Rajkai, K.; Standovár, T. Effects of gap size and associated changes in light and soil moisture on the understorey vegetation of a Hungarian beech forest. Plant Ecol. 2006, 183, 133-145. [CrossRef]

39. Marozas, V. Effect of the coniferous forest-grassland edge on ground vegetation in the mixed European forest zone, Lithuania. Dendrobiology 2014, 71, 15-22. [CrossRef]

40. Pankiw, N.A. Recreational Trail Impacts and Their Spatial Influence on Species Diversity and Composition. Master's Thesis, Ryerson University, Toronto, ON, Canada, 2011.

41. Pescott, O.L.; Stewart, G.B. Assessing the impact of human trampling on vegetation: A systematic review and meta-analysis of experimental evidence. PeerJ 2014, 2, e360. [CrossRef] [PubMed]

42. Roovers, P.; Bossuyt, B.; Gulinck, H.; Hermy, M. Vegetation recovery on closed paths in temperate deciduous forests. J. Environ. Manag. 2005, 74, 273-281. [CrossRef]

43. Scharenbroch, B.C.; Bockheim, J.G. Impacts of forest gaps on soil properties and processes in old growth northern hardwoodhemlock forests. Plant Soil 2007, 294, 219-233. [CrossRef]

44. Özcan, M.; Gökbulak, F. Effect of size and surrounding forest vegetation on chemical properties of soil in forest gaps. iForestBiogeosci. For. 2015, 8, 67-72. [CrossRef]

45. Kooch, Y.; Hosseini, S.M.; Mohammadi, J.; Hojjati, S.M. The effects of gap disturbance on soil chemical and biochemical properties in a mixed beech-hornbeam forest of Iran. Ecol. Balk. 2010, 2, 39-56.

46. Zhou, T.; Luo, X.; Hou, Y.; Xiang, Y.; Peng, S. Quantifying the effects of road width on roadside vegetation and soil conditions in forests. Landsc. Ecol. 2020, 35, 69-81. [CrossRef]

47. Tiebel, K.; Huth, F.; Wagner, S. Soil seed banks of pioneer tree species in European temperate forests: A review. IForest 2018, 11, 48-57. [CrossRef]

48. Wójcik, T.; Makuch-Pietraś, I.; Ćwik, A.; Ziaja, M. Anthropogenic changes in selected elements of the natural environment in the Lisia Góra forest nature reserve in Rzeszów. Sylwan 2020, 164, 246-253.

49. Thurston, E.; Reader, R.J. Impacts of experimentally applied mountain biking and hiking on vegetation and soil of a deciduous forest. J. Environ. Manag. 2001, 27, 397-409. [CrossRef] [PubMed]

50. Root-Bernstein, M.; Svenning, J.-C. Human paths have positive impacts on plant richness and diversity: A meta-analysis. Ecol. Evol. 2018, 8, 11111-11121. [CrossRef] [PubMed]

51. Gonzalez, M.; Ladet, S.; Deconchat, M.; Cabanettes, A.; Alard, D.; Balent, G. Relative contribution of edge and interior zones to patch size effect on species richness: An example for woody plants. For. Ecol. Manag. 2010, 259, 266-274. [CrossRef]

52. Erdős, L.; Krstonošić, D.; Kiss, P.J.; Bátori, Z.; Tölgyesi, C.; Škvorc, Ž. Plant composition and diversity at edges in a semi-natural forest-grassland mosaic. Plant Ecol. 2019, 220, 279-292. [CrossRef] 
53. de Casenave, J.L.; Pelotto, J.P.; Protomastro, J. Edge-interior differences in vegetation structure and composition in a Chaco semi-arid forest, Argentina. For. Ecol. Manag. 1995, 72, 61-69. [CrossRef]

54. Fontoura, S.B.; Ganade, G.; Larocca, J. Changes in plant community diversity and composition across an edge between Araucaria forest and pasture in South Brazil. Rev. Bras. Bot. 2006, 29, 79-91. [CrossRef]

55. Harper, K.A.; Macdonald, S.E.; Mayerhofer, M.S.; Biswas, S.R.; Esseen, P.-A.; Hylander, K.; Stewart, K.J.; Mallika, U.; Drapeau, P.; Jonsson, B.-G.; et al. Edge influence on vegetation at natural and anthropogenic edges of boreal forests in Canada and Fennoscandia. J. Ecol. 2015, 103, 550-562. [CrossRef]

56. Kostrakiewicz-Gierałt, K.; Pliszko, A.; Gmyrek-Gołąb, K. The effect of visitors on the properties of vegetation of calcareous grasslands in the context of width and distances from tourist trails. Sustainability 2020, 12, 454. [CrossRef]

57. Pickering, C.M.; Hill, W. Impacts of recreation and tourism on plant biodiversity and vegetation in protected areas in Australia. J. Environ. Manag. 2007, 85, 791-800. [CrossRef]

58. Roovers, P.; Verheyen, K.; Hermy, M.; Gulinck, H. Experimental trampling and vegetation recovery in some forest and heathland communities. Appl. Veg. Sci. 2004, 7, 111-118. [CrossRef]

59. Marzano, M.; Dandy, N. Recreational Use of Forests and Disturbance of Wildlife-A Literature Review; Forestry Commission Publication: Edinburg, UK, 2012; p. 40.

60. Sun, D. Trampling resistance, recovery and growth rate of eight plant species. Agric. Ecosyst. Environ. 1992, 38, 265-273. [CrossRef]

61. Littlemore, J.; Barker, S. The ecological response of forest ground flora and soils to experimental trampling in British urban woodlands. Urban Ecosyst. 2001, 5, 257-276. [CrossRef]

62. Rusterholz, H.-P.; Kissling, M.; Baur, B. Disturbances by human trampling alter the performance, sexual reproduction and genetic diversity in a clonal woodland herb. Perspect. Plant Ecol. Evol. Syst. 2009, 11, 17-29. [CrossRef]

63. Vujić, V.; Rubinjoni, L.; Selaković, S.; Cvetković, D. Small-scale variations in leaf shape under anthropogenic disturbance in dioecious forest forb Mercurialis perennis: A geometric morphometric examination. Arch Biol Sci. 2016, 68, 705-713. [CrossRef]

64. Angevine, M.W. Variations in the demography of natural populations of the wild strawberries Fragaria vesca and F. virginiana. J. Ecol. 1983, 71, 959-974. [CrossRef]

65. Czarnecka, B. Biological proprieties of Maianthemum bifolium (L.) F.W. Schm. polycormones under various ecological conditions. Acta Soc. Bot. Pol. 1986, 55, 659-678. [CrossRef]

66. Falińska, K. The biology of Mercurialis perennis L. polycormones. Acta Soc. Bot. Pol. 1982, 51, 127-148. [CrossRef]

67. Towpasz, K.; Szymska, M. Structure and dynamics of populations of Milium effusum L. in a forest near Polanka-Haller in the Wielickie Foothills (Southern Poland). Bot. Pap. 1983, 11, 109-142.

68. Avon, C.; Dumas, Y.; Bergès, L. Management practices increase the impact of roads onplant communities in forests. Biol. Conserv. 2013, 154, 24-31. [CrossRef]

69. Harper, J.; Williams, J.T.; Sagar, G. The behaviour of seeds in soil. I. The heterogeneity of soil surfaces and its role in determining the establishment of plants from seed. J. Ecol. 1965, 53, 273-286. [CrossRef]

70. Skálová, H.; Moravcová, L.; Čuda, J.; Pyšek, P. Seed-bank dynamics of native and invasive Impatiens species during a five-year field experiment under various environmental conditions. Neobiota 2019, 50, 75-95. [CrossRef]

71. Falińska, K.; Pirożnikow, E. Ecological structure of Geranium robertianum L. populations under natural conditions and in the garden. Ekol. Pol. 1983, 31, 93-121.

72. Pirożnikow, E. Seed bank in the soil of stabilized ecosystem of a deciduous forest (Tilio- Carpinetum) in the Białowieża National Park. Ecol. Pol. 1983, 31, 145-172.

73. Iluz, D. Zoochory: The Dispersal of Plants by Animals. In All Flesh Is Grass. Cellular Origin, Life in Extreme Habitats and Astrobiology; Dubinsky, Z., Seckbach, J., Eds.; Springer: Dordrecht, The Netherlands, 2010; pp. 199-214.

74. Pickering, C.; Mount, A. Testing the capacity of clothing to act as a vector for non-native seed in protected areas. J. Environ. Manag. 2009, 91, 168-179.

75. Pickering, C.; Mount, A. Do tourists disperse weed seed? A global review of unintentional human-mediated terrestrial seed dispersal on clothing, vehicles and horses. J. Sustain. Tour. 2010, 18, 239-256. [CrossRef]

76. Devlaeminck, R.; Bossuyt, B.; Hermy, M. Inflow of seeds through the forest edge: Evidence from seed bank and vegetation patterns. Plant Ecol. 2005, 176, 1-17. [CrossRef]

77. Jankowska-Błaszczuk, M. Variability of the soil seed banks in the natural deciduous forest in the Białowieża National Park. Acta Bot. Soc. Pol. 1998, 67, 313-324. [CrossRef]

78. Jankowska-Błaszczuk, M.; Kwiatkowska, A.J.; Panufnik, D.; Tanner, E. The size and diversity of the soil seed banks and the light requirements of the species in sunny and shady natural communities of the Białowieża Primeval Forest. Plant Ecol. 1998, 136, 105-118. [CrossRef]

79. Lin, L.; Cao, M. Edge effects on soil seed banks and understory vegetation in subtropical and tropical forests in Yunnan, SW China. For. Ecol. Manag. 2009, 257, 1344-1352. [CrossRef]

80. Danielewicz, W.; Wiatrowska, B.; Dajdok, Z.; Tokarska-Guzik, B. Rośliny naczyniowe obcego pochodzenia zadomowione w lasach Polski. Fragm. Flor. Geobot. Pol. 2020, 27, 451-471.

81. Mavimbela, L.; Sieben, E.J.J.; Procheş, Ş. Invasive alien plant species, fragmentation and scale effects on urban forest community composition in Durban, South Africa. N. Z. J. For. Sci. 2018, 48, 19. [CrossRef] 
82. Dyderski, M.K.; Jagodziński, A.M. Context-dependence of urban forest vegetation invasion level and alien species' ecological success. Forests 2019, 10, 26. [CrossRef]

83. Zając, M.; Zając, A.; Zemanek, B. (Eds.) Flora Cracoviensis Secunda (Atlas). s. xii + Institute of Botany; Jagiellonian University: Kraków, Poland, 2006; p. 291.

84. Tokarska-Guzik, B.; Dajdok, Z.; Zając, M.; Zając, A.; Urbisz, A.; Danielewicz, W.; Hołdyński, C. AlienPlants in Poland with Particular Reference to Invasive Species; General Directorate for Environmental Protection: Warszawa, Poland, 2012; p. 197.

85. Chatterjea, K. Assessment and demarcation of trail degradation in a nature reserve using GIS: Case of Bukit Timah Nature Reserve. Land Degrad. Dev. 2007, 18, 500-518. [CrossRef]

86. Van Winkle, J.E. Informal Trails and the Spread of Invasive Species in Urban Natural Areas: Spatial Analysis of Informal Trails and their Effects on Understory Plant Communities in Forest Park, Portland, Oregon. Master's Thesis, Portland State University, Portland, OR, USA, 2014. Paper 1841. 